\title{
MicroRNAs as Modulators of Oral Tumorigenesis-A Focused Review
}

\author{
Kumar Rishabh ${ }^{1,+}$, Soham Khadilkar ${ }^{1,+}{ }^{\text {, Aviral Kumar }}{ }^{1}$ D, Ishu Kalra ${ }^{1}$, Alan Prem Kumar ${ }^{2,3,4, *(D)}$ \\ and Ajaikumar B. Kunnumakkara ${ }^{1, *}$
}

1 Cancer Biology Laboratory and DBT-AIST International Center for Translational and Environmental Research (DAICENTER), Department of Biosciences and Bioengineering, Indian Institute of Technology (IIT) Guwahati, Guwahati, Assam 781039, India; rishabh18b@iitg.ac.in (K.R.); khadilka@iitg.ac.in (S.K.); aviral.kumar@iitg.ac.in (A.K.); ishukalraish2@gmail.com (I.K.)

2 Cancer Science Institute of Singapore, Department of Pharmacology, Yong Loo Lin School of Medicine, National University of Singapore, Singapore 117599, Singapore

3 NUS Centre for Cancer Research (N2CR), Yong Loo Lin School of Medicine, National University of Singapore, Singapore 117593, Singapore

4 National University Cancer Institute, National University Health System, Singapore 119074, Singapore

* Correspondence: authors: apkumar@nus.edu.sg (A.P.K.); kunnumakkara@iitg.ac.in (A.B.K.)

$\dagger$ These authors contributed equally to this work.

Citation: Rishabh, K.; Khadilkar, S.;

Kumar, A.; Kalra, I.; Kumar, A.P.

Kunnumakkara, A.B. MicroRNAs as Modulators of Oral TumorigenesisA Focused Review. Int. J. Mol. Sci. 2021, 22, 2561. https://doi.org/ $10.3390 /$ ijms 22052561

Academic Editor: Imad Kansau

Received: 4 February 2021

Accepted: 26 February 2021

Published: 4 March 2021

Publisher's Note: MDPI stays neutra with regard to jurisdictional claims in published maps and institutional affiliations.

Copyright: (c) 2021 by the authors. Licensee MDPI, Basel, Switzerland. This article is an open access article distributed under the terms and conditions of the Creative Commons Attribution (CC BY) license (https:/ creativecommons.org/licenses/by/ $4.0 /)$

\begin{abstract}
Oral cancers constitute the majority of head and neck tumors, with a relatively high incidence and poor survival rate in developing countries. While the five-year survival rates of the oral cancer patients have increased to $65 \%$, the overall survival for advanced stages has been at $27 \%$ for the past ten years, emphasizing the necessity for further understanding the etiology of the disease, diagnosis, and formulating possible novel treatment regimens. MicroRNAs (miRNAs), a family of small non-coding RNA, have emerged as master modulators of gene expression in various cellular and biological process. Aberrant expression of these dynamic molecules has been associated with many human diseases, including oral cancers. The deregulated miRNAs have been shown to control various oncogenic processes, including sustaining proliferative signaling, evading growth suppressors, resisting cell death activating invasion and metastasis, and inducing angiogenesis. Hence, the aberrant expression of miRNAs associated with oral cancers, makes them potential candidates for the investigation of functional markers, which will aid in the differential diagnosis, prognosis, and development of novel therapeutic regimens. This review presents a holistic insight into our understanding of the role of miRNAs in regulating various hallmarks of oral tumorigenesis.
\end{abstract}

Keywords: oral cancers; miRNAs; non-coding RNAs; invasion; apoptosis; metastasis

\section{Introduction}

Oral cancer constitutes a part of the head and neck squamous carcinoma (HNSCC), and is one of the most common cancers afflicting millions worldwide [1,2]. It mostly arises from the mucosal epithelial lining of the oral cavity, which includes the anterior of the tongue, buccal cavity, lips, and lower alveolar ridges $[3,4]$. Although the five-year survival rate is increased to $65 \%$, diagnosis at advanced stages leads to a five-year survival of only $27 \%$, necessitating the need for the development of early diagnosis and novel therapeutic approaches in combating this disease [5-7]. Tobacco chewing and alcohol consumption are the major risk factors associated with oral cancers [8]. Other factors include the chewing of areca nuts, poor oral health hygiene, betel leaf, and human papillomavirus (HPV) infection $[9,10]$. With the change in lifestyle and environmental factors, the incidence of oral cancer is increasing at an unprecedented rate in developing countries [11,12]. Treatment modalities mostly rely on the position of tumor, identification of risk type based on histopathology, and other comorbidities. At present, conventional therapeutic approaches for oral cancers involve surgical resection at tumor sites, with or without neck 
dissection or chemotherapy, followed by adjuvant radiotherapy [13]. These approaches present poor clinical outcomes in late stages with recurrence and distal metastasis being the most common [12,14-16]. Thus, a molecular-level understanding of the tumor dynamics, its heterogenicity, and its pathophysiology are imperative in the development of novel and more efficacious therapies.

The discovery of small non-coding RNA molecules in gene regulation has revolutionized the clinical realm, providing newer impetus in the identification of their mechanistic role in biological processes and human disease conditions. miRNAs are evolutionarily conserved, endogenous, small non-coding RNA molecules of about 18-24-nt in length that function as post-transcriptional gene regulators [17]. Since its identification in 1993 as small RNA molecule in Caenorhabditis elegans, it has been extensively studied and well-characterized over the past decades [18]. miRNAs are known to regulate various biological processes, such as proliferation, differentiation, apoptosis, immune response, and maintenance of homeostasis [19-23]. These small dynamic RNA molecules regulate gene expression by binding to the $3^{\prime}$-untranslated regions ( $3^{\prime}$-UTR) of target mRNAs, leading to post-transcriptional inactivation of the target gene, either by mRNA degradation or inhibiting translation [24]. Due to its variability in the binding region and imperfect complementary binding, a single miRNA can bind and target multiple mRNAs [25]. Dysregulation of these non-coding RNAs, due to genetic and epigenetic events, is found to disrupt the balance of these pleiotropically acting molecules, in turn contributing to many human disorders, including cancers [26,27]. Several studies have shown significant insight into miRNA's role in tumor development and progression since its first discovery in cancer [28]. A regulator of cell proliferation, apoptosis, invasion, migration, and stem cell maintenance, this noncoding RNA molecule, through recent studies, has also emerged as a controller of tumor microenvironment (TME) remodeling and tumor metastasis [29]. Primarily, two classes of miRNAs, oncomiRs and tumor suppressor miRs (TS-miRs), are observed that regulate the expression of oncogenes and tumor suppressor genes, respectively [30]. Accumulating evidence has shown insight into the functional role of the deregulated miRNAs in controlling the expression of their target mRNAs, leading to regulation of signaling pathways involved in oral cancer [31-33]. A total of 2300 true human mature miRNAs have been identified, but their action on target mRNAs is challenging to characterize due to their multi-target inherent nature. Although bioinformatics tools using different algorithms and parameters are used to analyze effective miRNA: mRNA interaction, their prediction accuracy is questionable [34]. Furthermore, miRNAs have been reported to possess unique signatures in different cancer types, grades and stages of tumors, making them a promising diagnostic and prognostic marker to detect the change in normal cellular function within the tumor tissues $[35,36]$. Hence, a deeper understanding of these dynamic molecules holds the key to the mechanism of oral cancer initiation and progression, which could further help in the clinical management of oral cancer. Through this review, we will provide insight into the role of these pleiotropically acting RNA molecules at different levels of hallmarks in oral tumorigenesis and reflect on the chances of understanding and manipulating these candidate molecules to develop newer diagnostic and therapeutic strategies.

\section{MicroRNA Biogenesis}

MiRNAs are highly conserved, small non-coding RNAs responsible for the modulation of $60 \%$ of protein-coding gene expression in the human genome, at the translational level. Increasing experimental evidence report miRNA genes to be distributed all along the genome $[37,38]$. In humans, about half of the identified miRNAs are found as clusters that are transcribed as polycistronic primary transcripts. miRNAs are present in four different regions namely, genomic clusters, i.e., exons of protein-coding regions, introns of proteincoding regions, and introns and exons of non-coding transcription units, but few of them are also found in long interspersed nuclear elements, such as repetitive sequences [39].

miRNA biosynthesis is an extremely well-coordinated multi-step sequential process that begins in the nucleus and ends in the cytoplasm, where miRNA carries out its primary 
function of post-transcriptional inactivation (Figure 1) [40]. They are transcribed by RNA polymerase II leading to the production of pri-miRNAs, which are precursor RNAs of several kilobases in length [41]. More than 30\% of pri-miRNAs are transcribed from introns of protein-coding genes, while some miRNAs are produced from specialized miRNA gene loci. An individual pri-miRNA can either form a single miRNA or produce a different cluster of miRNAs formed from a common miRNA primary transcript [42]. Drosha, a microprocessor enzyme of the RNase III enzyme family along with DiGeorge syndrome chromosomal (or critical) region 8 (DGCR8), a double-stranded RNA binding protein, is recruited for further processing of the capped and polyadenylated pri-miRNA. Processing of pri-mRNA results in the formation of pre-miRNAs, which are approximately 70 nucleotide segments folded into stem-loop structures [43]. This is followed by a guanosine triphosphate (GTP)-dependent transport of pre-miRNA by exportin-5 to the cytoplasm. In the cytoplasm, DICER1, and RNase III enzyme, further processes the pre-miRNA to produce mature double-stranded RNA of nearly 22 nucleotides in length [44]. One strand of the mature miRNA is hooked to miRNA induced silencing complex (miRISC complex) and with the help of DICER1 and Argonaute (AGO), which directs it to target the complementary strand of mRNA. This is generally termed as the canonical processing of miRNA biosynthesis [45]. Nonetheless, there have been findings according to which another subset of miRNA, termed as mirtrons, which are pre-miRNA-like hairpin structures, undergo splicing and debranching by evading the Drosha processing step. These structures directly enter the pathway at as exportin- 5 substrates. This mechanism is commonly known as the non-canonical pathway of miRNA processing which is observed in miRNA production using various other microprocessor molecules [46]. Though most miRNAs act in a RISC dependent manner, a confined number of miRNAs in the nucleus, are known to work non-canonically by demonstrating RISC independent activity. One major form of non-canonical pathway for miRNA biosynthesis is the Mirtron pathway, where the mature miRNA is processed with the Drosha independent mechanism [47]. Here, the $5^{\prime}$ and $3^{\prime}$ ends of pre-miRNA are cleaved by spliceosomes and debranching enzymes to generate short hairpin structures. These pre-miRNA structures are then exported to cytoplasm by Exportin 5, where it is cleaved by DICER enzymes. The major difference between the two different forms of miRNA biosynthesis pathways is the bypassing of microprocessor step with the splicing machinery to merge with the canonical pathway of miRNA biogenesis [47]. Recent studies have shown variability of Mirtron within the species of mammalian and invertebrate origin in terms of splice acceptor sites, GC content and hairpin loop arrangement. Still, Mirtron has emerged as crucial regulators of gene expression and further studies are needed to elucidate the exact biogenesis and mechanistic role of these small hairpin structures in disease etiology [48]. Thus, miRNA portrays tremendous versatility in the role it plays within the cell. Through different mechanisms, miRNAs in both cytoplasm and nucleus have established their role in regulating gene expression [49]. miRNA induced silencing complex (miRISC) within the nucleus is found to regulate the expression of small RNA molecules like long non-coding RNA through post-transcriptional degradation. Studies have also revealed the role of miRNAs regulating the conversion of the pri-miRNA into pre-miRNA through feedback loop mechanisms [50]. The evidence on colocalization of miR-206 and 28s-rRNA has emanated inquiry into the role of miRNA in ribosomal biogenesis [51]. Similarly, recent research indicates miRNA being a part of the different cellular processes, such as alternate splicing and transcriptional gene activation and silencing [52]. 


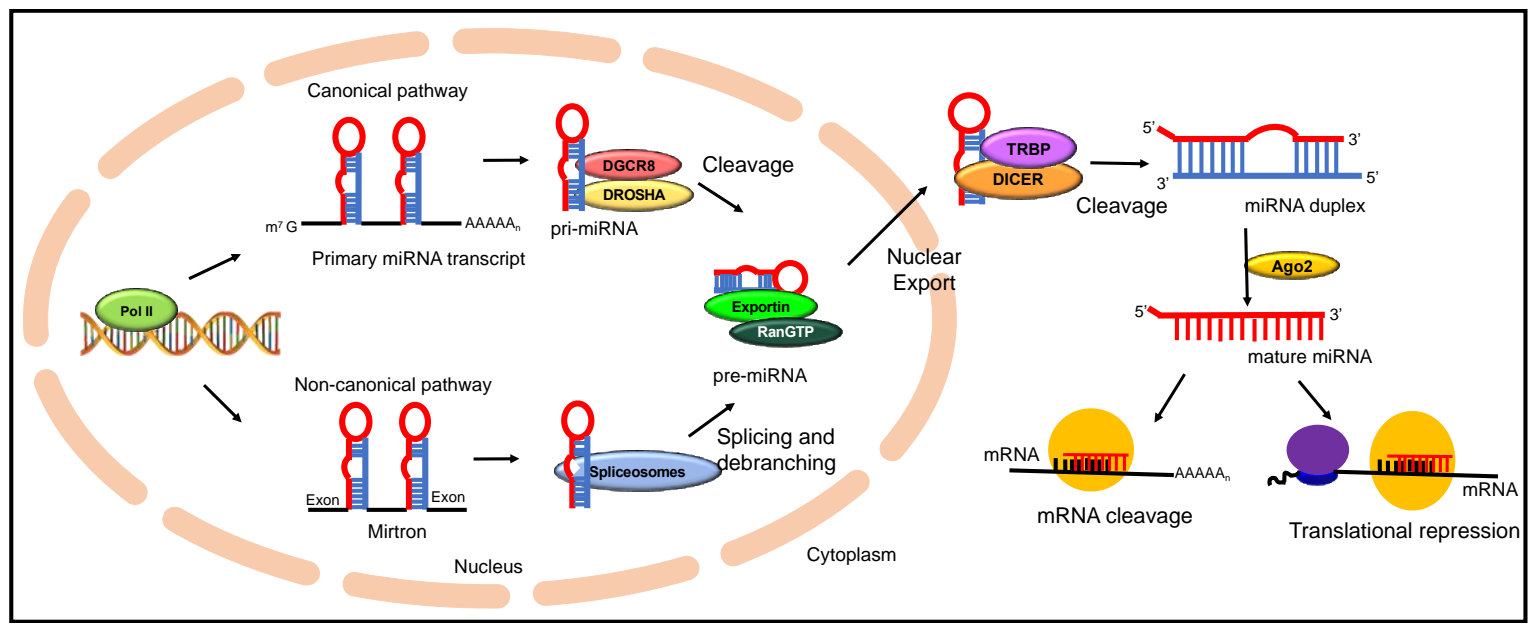

Figure 1. A schematic illustrating the miRNA biogenesis and its regulation of gene expression by post-transcriptional inactivation.

\section{MicroRNAs in Oral Cancer Pathogenesis}

MiRNAs being the master regulator are known to modulate various hallmarks of cancer, either by acting as oncogenes or tumor suppressor genes (Figure 2). miRNA altered signatures disturb the biological balance that modulates various signaling pathways leading to disease onset and progression. A growing body of research now aims to unravel the miRNA regulatory network code involved in oral tumor pathogenesis (Table 1). From a molecular outlook, since oral cancer is complex and relates to the host pathophysiology, understanding these miRNA molecules, and their regulation would be a crucial step in developing a more targeted type of cancer therapy.

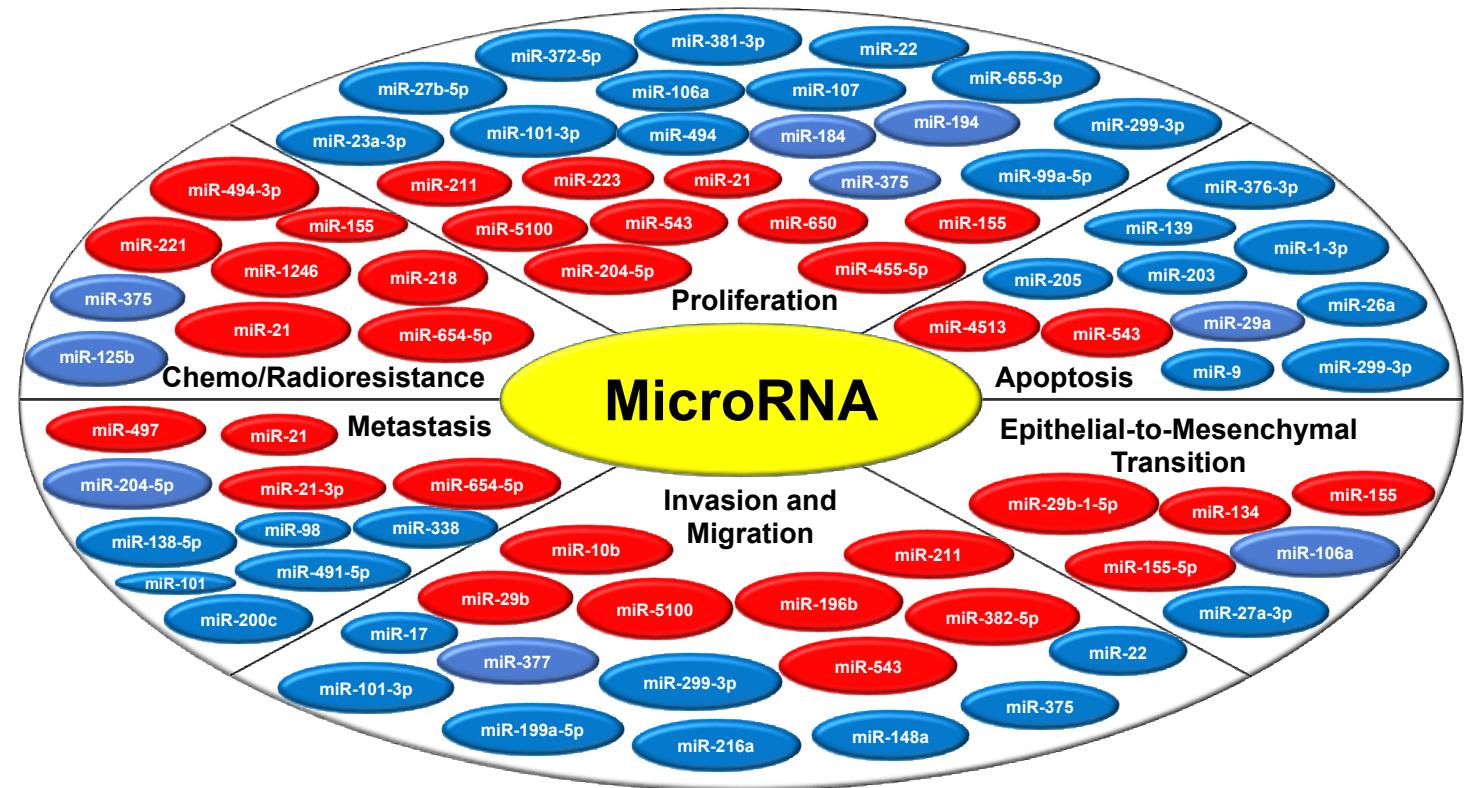

Figure 2. MicroRNA modulates oral tumorigenesis by regulating various hallmarks of cancer. The miRNAs represented in the red circle indicates the tumor promoting or oncogenic miRNAs and the miRNAs represented in the blue circle depicts the tumor suppressor miRNAs. 
Table 1. Different microRNAs and their targets involved in oral cancer initiation and progression.

\begin{tabular}{|c|c|c|c|}
\hline miRNA & Target Gene & Mechanism or Functions & Reference \\
\hline $\operatorname{miR}-1 \downarrow$ & SLUG & $\uparrow$ Tumorigenicity and invasiveness & [53] \\
\hline $\operatorname{miR}-1-3 p$ & DKK1 & $\downarrow$ Transit of SCC-4 cells from G0/G1 to S and $\uparrow$ apoptosis & [54] \\
\hline $\operatorname{miR}-9 \downarrow$ & $\mathrm{CDK} 4 / 6 \downarrow$ & $\uparrow$ Cell-cycle arrest at G0/G1 and $\uparrow$ apoptosis & [55] \\
\hline $\operatorname{miR}-10 \mathrm{a} \uparrow$ & GLUT1 & $\uparrow$ Cell proliferation and glucose metabolism & [56] \\
\hline $\operatorname{miR}-10 \mathrm{~b} \uparrow$ & & $\uparrow$ Cell migration and invasion & [57] \\
\hline $\operatorname{miR}-16 \downarrow$ & AKT3 and BCL2L2 & $\downarrow$ Tumor & [58] \\
\hline $\mathrm{miR}-17 / 20 \mathrm{a} \downarrow$ & ITG $\beta 8$ & $\downarrow$ Cell migration & [59] \\
\hline $\operatorname{miR}-18 a-5 p \uparrow$ & Smad2 & $\downarrow$ E-cadherin, and $\uparrow$ Smad7 TGF $\beta, \alpha$ SMA, vimentin. & [60] \\
\hline miR-21 & TNF- $\alpha$ & Cell proliferation & [61] \\
\hline $\operatorname{miR}-21 \uparrow$ & & $\uparrow$ Tumor size, metastasis and local invasion & [62] \\
\hline $\operatorname{miR}-21-3 p \uparrow$ & & $\uparrow$ Metastasis & [63] \\
\hline $\operatorname{miR}-22 \downarrow$ & NLRP3 & $\downarrow$ Cell proliferation, migration & [64] \\
\hline $\operatorname{miR}-23 a-3 p \downarrow$ & FGF2 $\uparrow$ & $\downarrow$ Cell proliferation & [65] \\
\hline $\operatorname{miR}-23 b \downarrow$ & $\mathrm{MET} \uparrow$ & $\downarrow$ Cell migration, invasion & [66] \\
\hline $\operatorname{miR}-26 a$ & MCL-1 $\downarrow$ & $\uparrow$ Apoptosis & [67] \\
\hline $\operatorname{miR}-27 a-3 p$ & YAP1 & $\downarrow$ EMT & [68] \\
\hline $\operatorname{miR}-27 \mathrm{~b} \downarrow$ & MET $\uparrow$ & $\downarrow$ Cell migration, invasion & [66] \\
\hline $\operatorname{miR}-27 \mathrm{~b} \downarrow$ & $\mathrm{TCTP} \downarrow$ & Novel plasma biomarker & [69] \\
\hline $\operatorname{miR}-29 \mathrm{a} \downarrow$ & MMP2 $\uparrow$ & $\downarrow$ Cancer invasion and anti-apoptosis & [70] \\
\hline miR-29b & CX3CL1 $\downarrow$ & $\uparrow$ Cell migration and tumorigenesis & [71] \\
\hline miR-29b-3p $\downarrow$ & IL32/AKT & $\downarrow$ Migration and invasion of OSCC cells & {$[72]$} \\
\hline miR-29b-1-5p $\uparrow$ & CDH1 & $\uparrow \mathrm{EMT}$ & [73] \\
\hline $\operatorname{miR}-31 \uparrow$ & CXCL12 $\downarrow$ & $\uparrow$ Progression from pre-cancer to cancer & {$[74]$} \\
\hline $\operatorname{miR}-31 \uparrow$ & SIRT3 & $\downarrow$ Mitochondrial activity and $\uparrow$ oxidative stress & [75] \\
\hline $\operatorname{miR}-31-5 p$ & ACOX1 & $\uparrow$ Tumorigenic fitness and $\uparrow$ cell migration and invasion & [76] \\
\hline $\operatorname{miR}-34 \mathrm{a} \downarrow$ & IL6R & $\begin{array}{l}\downarrow \text { Cell proliferation, G1 phase arrest, metastasis and } \\
\text { EMT }\end{array}$ & [77] \\
\hline $\operatorname{miR}-98 \downarrow$ & IGF1R & $\downarrow$ Tumor cell growth and metastasis & [78] \\
\hline $\operatorname{miR}-99 \mathrm{a} \downarrow$ & mTOR & $\uparrow$ Growth and survival of OSCC & [79] \\
\hline $\operatorname{miR}-99 \mathrm{a} \downarrow$ & MTMR3 $\uparrow$ & $\uparrow$ Anti-metastasis & [80] \\
\hline miR-99a-5p $\downarrow$ & NOX4个 & $\downarrow$ Proliferation, migration, and invasion & [81] \\
\hline $\operatorname{miR}-101 \downarrow$ & ZEB1 & $\downarrow$ Growth, metastasis, and apoptosis resistance & [82] \\
\hline $\operatorname{miR}-101-3 p \downarrow$ & COL10A1 $\uparrow$ & $\downarrow$ Proliferation, invasion, and migration & [83] \\
\hline miR-106a $\downarrow$ & LIMK1 & $\downarrow$ Proliferation and EMT & {$[84]$} \\
\hline $\operatorname{miR}-107 \downarrow$ & TRIAP1 & $\downarrow$ Cell proliferation and migration & [85] \\
\hline $\operatorname{miR}-124 \downarrow$ & CCL2 and IL-8 & $\downarrow$ Tumor growth & [86] \\
\hline $\operatorname{miR}-125 \mathrm{~b} \downarrow$ & PRXL2A $\uparrow$ & $\downarrow$ Oral oncogenicity & [87] \\
\hline miR-126 $\downarrow$ & VEGF-A & $\uparrow$ Angiogenesis and lymphangiogenesis & [88] \\
\hline $\operatorname{miR}-133 a-3 p \downarrow$ & COL1A1 $\uparrow$ & $\downarrow$ Proliferation, invasion, and mitosis & [89] \\
\hline $\operatorname{miR}-134 \uparrow$ & PDCD7 $\downarrow$ & $\downarrow$ E-cadherin expression & [90] \\
\hline
\end{tabular}


Table 1. Cont.

\begin{tabular}{|c|c|c|c|}
\hline miRNA & Target Gene & Mechanism or Functions & Reference \\
\hline miR-138 $\downarrow$ & YAP1 & $\downarrow$ Tumor and proliferation & {$[91,92]$} \\
\hline miR-138-5p $\downarrow$ & $\Delta \mathrm{Np} 63 \uparrow$ & $\downarrow$ Growth, metastasis, and cancer stemness & [93] \\
\hline miR-139 & & $\uparrow$ Apoptosis through AKTsignaling & [94] \\
\hline miR-139-5p $\downarrow$ & HOXA9 $\uparrow$ & $\downarrow$ Tumorigenesis and progression & [95] \\
\hline miR-143 $\downarrow$ & HK2 & $\downarrow$ Growth of OSCC & [96] \\
\hline $\operatorname{miR}-145 \downarrow$ & c-Myc and CDK6 & $\downarrow$ Cell proliferation and $\uparrow$ G1 phase arrest & [97] \\
\hline miR-145-5p $\downarrow$ & & $\uparrow$ Effects of photodynamic therapy and phototoxicity & [98] \\
\hline miR-146a $\downarrow$ & SOX2 & $\downarrow$ Aggressiveness of OSCC & [99] \\
\hline miR-146a-5p $\uparrow$ & TRAF6 $\downarrow$ & $\uparrow$ Proliferation, $\downarrow$ TGF- $\beta$ signaling & {$[100]$} \\
\hline miR-148b-3p & RALBP1 & $\downarrow$ Tumor & [101] \\
\hline $\operatorname{miR}-155 \uparrow$ & & $\downarrow$ Prognosis & [102] \\
\hline $\operatorname{miR}-155 \uparrow$ & CDC73 $\downarrow$ & $\uparrow$ Cell proliferation & [103] \\
\hline miR-155-5p & & $\downarrow$ E-cadherin & {$[104]$} \\
\hline $\operatorname{miR}-155-5 \mathrm{p} \uparrow$ & ARID2 & $\uparrow$ Proliferation, migration, and invasion & [105] \\
\hline $\operatorname{miR}-181 \mathrm{a} \downarrow$ & K-ras & $\begin{array}{c}\downarrow \text { Tumor, K-ras protein level, and luciferase activity of } \\
\text { vectors }\end{array}$ & [106] \\
\hline miR-182-5p $\uparrow$ & CAMK2N1 & $\uparrow$ Growth, $\downarrow$ activation of AKT, ERK1/2, and NF- $\mathrm{BB}$ & [107] \\
\hline miR-184 & UCA1 and SF1 & $\downarrow$ Cell proliferation & [108] \\
\hline miR-186 $\downarrow$ & PTPN11 & $\downarrow$ Tumor, $\downarrow$ signaling of ERK, and AKT & [109] \\
\hline miR-186 $\downarrow$ & & Potential biomarker & [110] \\
\hline $\operatorname{miR}-188 \downarrow$ & SIX1 & $\downarrow$ Proliferation and invasion & [111] \\
\hline $\operatorname{miR}-194 \downarrow$ & AGK & $\begin{array}{c}\downarrow \text { Cell proliferation and inhibits PI3K/AKT/FoxO3a } \\
\text { signaling pathway }\end{array}$ & [112] \\
\hline miR-195-3p & CCL4 & $\downarrow$ VEGF-C expression and lymphangiogenesis & [113] \\
\hline miR-195-5p $\downarrow$ & TRIM14 & $\downarrow$ Proliferation, migration, and invasion & {$[114]$} \\
\hline miR-196b $\uparrow$ & & $\uparrow$ Migration and Invasion & [115] \\
\hline miR-199a-5p $\downarrow$ & SOX4 & $\downarrow$ Migration and invasion of cells via targeting SOX4 & [116] \\
\hline miR-199a-5p $\downarrow$ & $\mathrm{IKK} \beta$ & $\begin{array}{l}\downarrow \text { Tumor via IKK } \beta / \text { NF- } \kappa B \text { signaling pathway, } \uparrow \text { G0/G1 } \\
\text { cell cycle arrest }\end{array}$ & [117] \\
\hline $\operatorname{miR}-200 \mathrm{c} \downarrow$ & HOC313 & $\downarrow$ Tumor metastasis & {$[118]$} \\
\hline miR-200c-3p & CHD9 and WRN & $\uparrow$ Invasion of OSCC & [119] \\
\hline miR-203 $\downarrow$ & YES-1 $\uparrow$ & $\downarrow$ Oncogenic activity and $\uparrow$ apoptosis & [120] \\
\hline $\operatorname{miR}-203 \downarrow$ & BMI-1 & $\uparrow$ Apoptosis & [121] \\
\hline miR-203 & SEMA6A & $\uparrow$ Apoptosis & [122] \\
\hline miR-204-5p $\downarrow$ & CXCR4 $\uparrow$ & $\downarrow$ Proliferation and metastasis of OSCC cells & [123] \\
\hline $\operatorname{miR}-205 \downarrow$ & AXIN2 $\uparrow$ & $\downarrow$ Oral carcinoma oncogenic activity & [124] \\
\hline $\operatorname{miR}-205 \downarrow$ & IL-24 & $\uparrow$ Apoptosis & [125] \\
\hline miR-205-5p $\downarrow$ & TIMP2 & $\begin{array}{l}\downarrow \text { Invasiveness, regulates TIMP2 gene and activates } \\
\text { proMMP2 }\end{array}$ & [126] \\
\hline $\operatorname{miR}-211 \uparrow$ & BIN1 & $\begin{array}{l}\uparrow \text { Proliferation, migration, and invasion, can inhibit the } \\
\text { EGFR/MAPK pathway }\end{array}$ & [127] \\
\hline $\operatorname{miR}-214 \uparrow$ & RASSF5 $\downarrow$ & $\begin{array}{l}\downarrow \text { FOXO3a phosphorylation, BIM expression, caspase } 3, \\
\text { and apoptosis }\end{array}$ & [128] \\
\hline
\end{tabular}


Table 1. Cont.

\begin{tabular}{|c|c|c|c|}
\hline miRNA & Target Gene & Mechanism or Functions & Reference \\
\hline miR-216a & EIF4B & $\downarrow$ Proliferation, migration, and invasion & [129] \\
\hline $\operatorname{miR}-218 \uparrow$ & PPP2R5A & $\begin{array}{l}\uparrow \text { Cisplatin resistance via the PPP2R5A/Wnt signaling } \\
\text { pathway }\end{array}$ & [130] \\
\hline $\operatorname{miR}-218-5 p \downarrow$ & CD44-ROCK & $\uparrow$ Invasion by targeting the CD44-ROCK pathway & [131] \\
\hline $\operatorname{miR}-221 \downarrow$ & TIMP3 个 & $\uparrow$ Sensitivity of OSCC to Adriamycin & [132] \\
\hline $\operatorname{miR}-223 \uparrow$ & & Novel diagnostic biomarker & [133] \\
\hline $\operatorname{miR}-223 \uparrow$ & FBXW7 $\downarrow$ & $\uparrow$ Proliferation & [134] \\
\hline $\operatorname{miR}-299-3 p \downarrow$ & FOXP4 & $\downarrow$ Proliferation and migration, $\uparrow$ apoptosis & [135] \\
\hline $\operatorname{miR}-320 \downarrow$ & NRP1 & $\begin{array}{c}\downarrow \text { Migration, adhesion, and tube formation of vascular } \\
\text { endothelial cells }\end{array}$ & [136] \\
\hline $\operatorname{miR}-338 \downarrow$ & NRP1 & $\downarrow$ Growth and metastasis & [137] \\
\hline $\operatorname{miR}-340 \downarrow$ & GLUT1 $\uparrow$ & $\begin{array}{l}\uparrow \text { Lactate secretion, glucose uptake rate, and } \\
\text { proliferation of OSCC }\end{array}$ & [138] \\
\hline $\operatorname{miR}-372 \uparrow$ & LATS2 & $\downarrow$ LATS2 expression & {$[139]$} \\
\hline $\operatorname{miR}-373 \uparrow$ & LATS2 & $\downarrow$ Survival rate & [139] \\
\hline $\operatorname{miR}-375 \downarrow$ & PDGFA & $\begin{array}{l}\downarrow \text { Cell Migration and invasion by targeting } \\
\text { platelet-derived growth factor A }\end{array}$ & [140] \\
\hline $\operatorname{miR}-375 \downarrow$ & IGF-1R & $\begin{array}{l}\downarrow \text { Growth and enhances radiosensitivity, } \uparrow \text { cell cycle } \\
\text { arrest in G0/G1 phase }\end{array}$ & [141] \\
\hline $\operatorname{miR}-377 \downarrow$ & HDAC9 & $\downarrow$ Growth, migration, and apoptosis & [142] \\
\hline miR-381-3p & FGFR2 $\downarrow$ & $\downarrow$ Proliferation and cell cycle progression & [143] \\
\hline miR-382-5p & & $\uparrow$ Migration and invasion & [144] \\
\hline $\operatorname{miR}-424-5 p \uparrow$ & SOCS2 $\downarrow$ & $\uparrow$ Oncogenic activity by $\downarrow$ SOCS2 & [145] \\
\hline $\operatorname{miR}-429 \downarrow$ & ZEB1 & $\downarrow$ Growth of OSCC & [146] \\
\hline $\operatorname{miR}-450 \mathrm{a} \uparrow$ & TMEM182 & $\uparrow$ Motility, $\downarrow$ cell adhesion ability, and $\uparrow$ invasiveness & [147] \\
\hline $\operatorname{miR}-455-5 p \uparrow$ & $\mathrm{UBE} 2 \mathrm{~B} \downarrow$ & $\uparrow$ Proliferation and tumorigenesis & [148] \\
\hline miR-483-5p & & Novel diagnostic biomarker & [149] \\
\hline $\operatorname{miR}-486-3 p \downarrow$ & $\mathrm{DDR} 1 \uparrow$ & $\downarrow$ Tumor & {$[150]$} \\
\hline miR-491-5p $\downarrow$ & GIT1 $\uparrow$ & $\downarrow$ Migration, invasion, and lung metastasis & [151] \\
\hline $\operatorname{miR}-494 \uparrow$ & & Potential biomarker & [110] \\
\hline miR-494-3p & Bmi1 $\downarrow$ & $\uparrow$ Cellular senescence and $\uparrow$ radiosensitivity & [152] \\
\hline $\operatorname{miR}-495 \downarrow$ & Notch1 & $\downarrow$ Cell proliferation and invasion & [153] \\
\hline $\operatorname{miR}-497$ & SMAD7 & $\uparrow$ Metastasis & [154] \\
\hline $\operatorname{miR}-543 \uparrow$ & CYP3A5 & $\uparrow$ Proliferation, invasion, and migration, $\downarrow$ apoptosis & [155] \\
\hline $\operatorname{miR}-545 \downarrow$ & RIG-I & $\downarrow$ Tumor & [156] \\
\hline $\operatorname{miR}-596$ & LGALS3BP & $\downarrow$ Tumor & {$[157]$} \\
\hline $\operatorname{miR}-650 \uparrow$ & GFI1 & $\uparrow$ Proliferation, migration, and invasion & [158] \\
\hline $\operatorname{miR}-654-5 p \uparrow$ & GRAP $\downarrow$ & $\begin{array}{c}\uparrow \text { Metastasis and chemoresistance, activates Ras/MAPK } \\
\text { signaling and EMT }\end{array}$ & [159] \\
\hline miR-655-3p $\downarrow$ & MTDH & $\begin{array}{l}\downarrow \text { Cell proliferation and invasion by inhibiting } \\
\text { PTEN/AKT signaling }\end{array}$ & [160] \\
\hline miR-1246个 & CCNG2 & $\uparrow$ Cancer stemness and chemoresistance & [161] \\
\hline
\end{tabular}


Table 1. Cont.

\begin{tabular}{|c|c|c|c|}
\hline miRNA & Target Gene & Mechanism or Functions & Reference \\
\hline miR-1246 & DENND2D & $\uparrow$ Cell motility & [162] \\
\hline $\operatorname{miR}-1246 \uparrow$ & & $\downarrow$ Prognosis of OSCC & [163] \\
\hline $\operatorname{miR}-1254 \downarrow$ & CD36 & $\downarrow$ Tumor & [164] \\
\hline $\operatorname{miR}-3651 \uparrow$ & & Potential biomarker & [110] \\
\hline $\operatorname{miR}-4513 \uparrow$ & CXCL17 & $\begin{array}{l}\uparrow \text { Cell proliferation, migration, and invasion, promotes } \\
\text { apoptosis }\end{array}$ & [165] \\
\hline $\operatorname{miR}-5100 \uparrow$ & SCAI $\downarrow$ & $\uparrow$ Proliferation, migration, and invasion & [166] \\
\hline
\end{tabular}

The arrows illustrated in the first column of the table represent the expression levels of miRNA in oral cancer tissues/cell lines. The second column represent the targets of miRNA found in various studies. The third column indicates the mechanism of action of these miRNAs in modulating various hallmarks of oral tumorigenesis. $\uparrow$ denotes increase and $\downarrow$ depicts decrease in either in expression/ function of miRNAs.

\subsection{Proliferation}

Accumulating evidence has established the varied role of different miRNAs as essential regulators in the proliferation of oral cancer. miRNAs regulate oral cancer progression by targeting various transcription factors and proliferative pathways. Increased expression of miRNA-10a promoted oral squamous cell carcinoma (OSCC) cell proliferation through the regulation of glucose metabolism by glucose transporter 1 (GLUT1) levels. Furthermore, miRNA-10a and GLUT1 were found to be enriched in oral cancer tissues as compared to healthy controls [56]. In another study, miR-211 was found to promote proliferation in OSCC by targeting the bridging integrator 1 protein (BIN1) [127]. Mir-21 was reported to regulate the proliferation in SCC- 15 cells by targeting TNF- $\alpha$ expression, without inducing any effect on the cellular apoptotic pathway [61]. A study identified cytochrome P450 family 3 subfamily A member 5 (CYP3A5) as a direct target of miR-543 using in-silico analysis and dual-luciferase reporter assays. The results of the study suggested that miR- 543 serves a vital role in OSCC proliferation [155]. Another study suggested the miR-375/SLCA11 axis as a major detrimental factor in promoting proliferation in CAL-27 and Tca8113 cell lines [167]. Fang, Z. et al., (2017) demonstrated miR-184 as a tumor suppressor gene by modulating the expression of long non-coding RNA urothelial cancer-associated 1 (UCA1) and SF1. Reduction in miR-184 levels reversed the tumor-suppressive effects in OSCC cell populations [108].

Increasing experimental evidences have implicated that miRNAs can also act as tumor suppressor genes resulting in suppression of oral cancer progression. Knockdown of miR-5100 suppressed proliferation of OSCC cells by increasing the populations of cells in the G1 and G2 phases, and subsequent reduction in the S phase [166]. In another study, fibroblast growth factor receptor 2 (FGFR2) was downregulated by miR-381-3p through direct interactions with its $3^{\prime}$ untranslated region. Knockdown of FGFR2 recapitulated the growth-suppressive effect of miR-381-3p. Conversely, restoring FGFR2 expression attenuated miR-381-3p-induced effects in OSCC cells [143]. miR-299-3p was found to inhibit oral squamous cell carcinoma cell proliferation by targeting forkhead box P4 (FOXP4) expression thereby promoting apoptosis [135]. The overexpression of miR-107 was identified to inhibit OSCC cell proliferation and target TP53 regulated inhibitor of apoptosis 1 (TRIAP1) to regulate the gene expression [85]. In another study, it was discovered that the downregulation of miR-4513 expression inhibits cell proliferation by CXCL17, which is a direct target of miR-4513. Knocking down the expression of CXCL17, inhibited the effects of miR-4513 on OSCC cell behaviors [165]. miR-494 repressed the expression of homeobox A10 (HOXA10) levels and was also observed to reduce the proliferation of oral cancer cells [168]. In a study, miR-655 was found to suppress cell proliferation in OSCC by directly targeting metadherin, a cell surface tumor-associated protein through PTEN/AKT pathway [160]. Downregulation of miR-30a-5p decreased the levels of FAP which led to the suppression of proliferation in OSCC cells [169]. An analysis of miR-101-3p showed 
that exosomes derived from human bone marrow mesenchymal stem cells overexpressing miR-101-3p suppressed oral cancer cell proliferation. Furthermore, it was observed that COL10A1 was upregulated, while miR-101-3p downregulated in oral tumor samples, and $\mathrm{miR}-101-3 p$ was directly targeting COL10A1 as verified by dual-luciferase reporter gene assay [83]. Similarly, miR-133a-3p was also found to regulate COL1A1 expression levels, thereby inhibiting the proliferation in various oral cancer cell lines [89]. In another study, it was found that LIM Domain Kinase 1 (LIMK1) is a direct target of miR-106a in OSCC cells and it inhibited the cell proliferation by directly decreasing LIMK1 expression [84]. mir-27b-5p and miR-372-5p were reported to bind to the $3^{\prime} \mathrm{UTR}$ region of proliferating cell nuclear antigen (PCNA), hence reducing proliferation in OSCC cells [170]. Chen, F. et al. (2019) analyzed the correlation between miR-23a-3p and prognosis of oral cancer patients. It was found that fibroblast growth factor 2 (FGF2) was revealed as a direct target of miR-23a-3p, based on luciferase assays and immunoblotting. Moreover, expression of miR23a-3p and FGF2 was found to be significantly downregulated and upregulated in OSCC tissues respectively [65]. Apart from these, other studies have implicated different miRNAs (miR-22 [64], miR-34a [77], miR-99a-5p [81], miR-138 [91,92], miR-145 [97], miR-155 [103], miR-155-5p [105], miR-188 [111], miR-194 [112], miR-195-5p [114], miR-204-5p [123], miR211 [127], miR-216a [129], miR-223 [134], miR-340 [138], miR-455-5p [148], miR-495 [153], $\mathrm{miR}-650$ [158]) to be involved in proliferation of oral cancer. Hence a plethora of literature indicated the immense role of miRNAs in regulating proliferation in oral cancers and targeting these non-coding RNA molecules can help in circumventing this deadly oral disease.

\subsection{Apoptosis}

Apoptosis is a naturally acquired programmed cell death, which is crucial for normal biological process through the removal of unrepaired damaged cells [171,172]. Deregulation in apoptotic pathways has been associated with various human diseases, including cancers [173-175]. Since the previous decade, our understanding of the miRNA's role in regulating cell death has increased exponentially. Many reports have linked various apoptotic genes as a direct target of miRNAs and their underlying importance in oral tumor progression and drug resistance. Increased expression of miR-101-3p and miR-199b-5p promoted apoptosis by suppressing BICC1 expression in TSCCA and SSC-9 cells [176]. A study showed that miR-203 induces the apoptosis of YD-38 human oral cancer cells by directly targeting semaphorin 6A (SEMA6A), suggesting its potential application in anticancer therapeutics [122]. Later it was discovered that overexpression of miR-203 significantly increased not only DNA segmentation but also the apoptotic population in YD-38 cells. Microarray analysis revealed that the expression of the polycomb complex protein gene Bmi-1, a representative oncogene, was greatly downregulated by miR-203 in YD-38 cells [121]. Another study reported the functional role of miR-376c-3p in regulating the cell cycle and apoptosis of human oral squamous cancer cells by suppressing homeobox B7 (HOXB7). It was also involved in inducing G1/G0 arrest and directing apoptosis in SCC-25 cells [177].

In another study, miR-26a was found to be overexpressed along with Bim and Bax, in cells treated with metformin. These results suggest that the anti-proliferative nature of metformin in KB human oral cancer cells might result partly due to the induction of apoptosis by downregulation of Mcl-1 levels by miR-26a [67]. It was found that miR-139 can induce apoptosis by regulating the AKT signaling pathway in Tca8113 cells which might lead to the development of a more effective method for the treatment of oral cancer [94]. miR-548d-3p is known to inhibit apoptosis by regulating the JAK signal transducer and activator of transcription (STAT) signaling pathway through binding to the $3^{\prime}$ UTR region of SOCS5 and SOCS6. In a recent study long non-coding RNA maternally expressed gene 3 (MEG3) was shown to promote apoptosis by sponging the levels of miR-548d-3p [178]. Another study showed that overexpression of miR-486-3p led to the growth inhibition and induction of apoptosis which was a similar phenotype observed by knockdown of 
discoidin domain receptor 1 (DDR1). It led to the conclusion that miR-486-3p functions as a tumor suppressor in oral cancer by targeting DDR1. Moreover, it was also suggested that miR-486-3p has the possibility of being transcriptionally co-regulated with its host gene ANK1 through epigenetic repression when treated with DNA methylation inhibitor elucidating its potent role in targeting apoptosis [150]. miR-214 expression was observed to be elevated and RASSF5 was down-regulated in oral cancer cell lines. Moreover, miR-214 regulated KB cell apoptosis through targeted inhibition of RASSF5 expression, FOXO3a phosphorylation, and BIM expression, suggesting its plausible application as a novel therapeutic oral cancer target [128]. Shang, A. et al. (2018) investigated the functional role of miR-9 in the pathogenesis of oral squamous cell carcinoma. Downregulation of miR-9 was observed in tumor tissues and forced expression of the same promoted apoptosis via targeting cyclin-dependent kinase 4/6 (CDK4/6) proliferative pathways [55]. miR-155 was found to be upregulated in OSCC patients' samples and further experimentation reported that inhibition of miR-155 directly target p27Kip1, a cell checkpoint inhibitor to induce G1 arrest, increased cleaved caspase-3 activity, and promoted apoptosis in Tca8113 cells [179]. Moreover, other miRNAs (miR-1-3p [54] miR-29a [70], miR-101 [82], miR-205 [125], miR377 [142], miR-543 [155], miR-4513 [165]) have been found to play a crucial role in regulating apoptosis in oral tumorigenesis. Hence, these results indicate the importance of miRNA in modulating the apoptotic pathways, which result in the progression of oral cancers.

\subsection{Epithelial-To-Mesenchymal Transition (EMT)}

Studies carried out over the past decades have shown the detrimental role of EMT in increasing the morbidity and mortality of human cancers [180,181]. The process, characterized by the loss of cell-cell adhesion, apical-basal polarity, and increment in the motility of cell is known to be controlled by a set of molecules that play the role of effectors, regulators, and inducers of EMT [182-184]. A piece of robust transcriptional machinery is essential for monitoring the expression of the epithelial and mesenchymal markers during EMT $[185,186]$. miRNAs being the regulator of genetic code, plays a pivotal role in the induction of EMT phenotype in oral cancers. miR-155-5p expression might contribute to EMT-associated OSCC progression and serve as a biomarker for predicting relapse, especially for patients with early-stage OSCC. miR-155-5p has a multifaceted role in regulating various EMT machinery by regulating different transcription factors and signaling pathways. A negative correlation was noted between miR-155-5p and E-cadherin expression, suggesting that miR-155-5p plays an important role in EMT. Moreover, miR-155-5p was found to assist EMT either by inducing transforming growth factor $\beta 1$ or through the phosphoinositide 3-kinase/serum and glucocorticoid-regulated kinase $3 / \beta$-catenin signaling pathway. Furthermore, miR-155-5p inhibitor transfected cells showed both, an increase in a suppressor of cytokine signaling 1 (SOCS1) and a decrease in transcription factor signal transducer and activator of transcription 3 (STAT3) in HSC-3 OSCC cells, possibly suggesting that the activation of SOCS1 causing downregulation of STAT3 by inhibiting the action of miR-155-5p. miR-155 also led to the downregulation of BCL6 expression and an increase in cyclin D2 expression. This helped in the proliferation, migration, and invasion of CAL27 OSCC cells as STAT3 generally functions as a tumor promoter in different malignancies [187-190]. It is already a well-established fact that the BCL6 promotes EMT by the Zinc finger E-box binding homeobox 1 (ZEB1)-mediated transcriptional repression of Ecadherin in breast cancer cells. Thus, the study data from OSCC tissue samples established a quantitative association between miR-155-5p and E-cadherin expression, its relapse, and disease-free survival (DFS). Therefore, highlighting that miR-155-5p is potentially a key modulator to determine the aggressiveness and the chance for relapse in OSCC [104]. Another study established the Yes-associated protein-1 (YAP1) as a direct target gene of miR-27a-3p. An increase in miR-27a-3p could significantly decrease YAP1 expression along with other EMT-associated markers in OSCC cell lines, including Twist and Snail. Further studies revealed that miR-27a-3p downregulated the EMT-related molecules, possibly through the regulation of SRY-box 2 (Sox2) via the YAP1-OCT4-Sox2 signaling axis. This 
study found that miR-27a-3p could inhibit the YAP1 directly by post-transcription silencing and therefore, potentially suppress the EMT process. Thus miR-27a-3p is an important player for the invasion and metastasis in OSCC through EMT inhibition [68]. Knockdown of miR-29b-1-5p in OSCC suppressed the EMT, which was regained by the forced expression of c-Met. Moreover, cadherin 1 (CDH1) was a direct target of miR-29b-1-5p possibly suggesting that the miR-29b-1-5p acts as an oncogenic miRNA that works in tandem with c-Met to induce EMT in OSCC cells [73]. Another study found that the level of miR-106a decreased significantly, whereas the expression of LIMK1 significantly increased in OSCC cell lines. EMT and proliferation were severely inhibited by the knockdown of LIMK1 in OSCC cells. Luciferase reporter assay confirmed that miR-106a directly targets LIMK1. Thus, the study concluded that there is an inverse relationship between cell proliferation and EMT and LIMK1 expression [84]. Thus, various miRNA's play a vital role in epithelial to mesenchymal transition in oral cancer leading to tumor progression.

\subsection{Invasion and Migration}

The dissemination of a tumor cell is a complex phenomenon involving migration and invasion as key characteristic features of metastatic tumors [191,192]. Increasing lines of evidence advocate miRNAs as major players regulating the migration and invasion of oral cancer. Experimental analysis of cancer-associated fibroblast-derived exosomal miR-382-5p led to the conclusion that it promoted the invasion and migration of OSCC. Moreover, the cancer-associated fibroblast (CAF) density in tumor tissues was found to be relevant to OSCC lymph node metastasis and the tumor-node-metastasis (TNM) stage. Furthermore, it was revealed that miR-382-5p was overexpressed in CAFs compared with adjacent normal tissue, and upregulation of miR-382-5p was responsible for promoting OSCC cell migration and invasion [144]. miR-196b was significantly overexpressed in OSCC tissues compared with the corresponding adjacent normal tissue samples. Moreover, it was found that the epigenetic regulation of miR-196b expression plays a pivotal role in modulating cell migration and cell invasion during OSCC progression [115]. An analysis of miR-211 led to the conclusion that it promotes invasion and migration ability of OSCC cells via targeting the bridging integrator 1 protein [127]. Another study discovered that miR-29b promoted OSCC cell migration by downregulating CX3CL1, a cell-cell adhesion regulator, which plays a pivotal role in miR-29b-regulated OSCC cell migration machinery [71]. Wei, Z. et al. (2019) demonstrated that the invasion and migration attributes of OSCC cells were drastically reduced after treatment with miR-5100 inhibitor. Upregulation of miR-5100 was observed with concomitant downregulation of suppressor of cancer cell invasion (SCAI) levels in OSCC cells. Moreover, SCAI was verified as a direct target of miR-5100 [166].

MiRNAs are also known to inhibit the invasion and migration of oral cancer and could be used as a novel therapeutic strategy for metastatic cancer treatments. Recently, $\mathrm{miR}-29 \mathrm{~b}-3 \mathrm{p}$ was shown to act as a guarder that suppressed the migration of OSCC cells. It was reported that miR-29b-3p regulated IL-32 through AKT signaling via direct binding to the $3^{\prime}$ untranslated region of the IL-32 mRNA transcript [72]. In another study, miR-4513 expression was found to be elevated in the OSCC cell lines and the forced downregulation of miR-4513 expression inhibited cell invasion and migration in OSCC [165]. Similar reports of increased expression of miR-299-3p through introduction of mimics were found to inhibit oral squamous cell carcinoma cells proliferation and migration [135]. Upregulation of miR543 promoted the invasion and migration of OSCC cell lines suggesting its oncogenic role in oral cancers [155]. In vitro experiments using rescue of miR-377 resulted in repressed cell growth, induced apoptosis, and reduced cell migration. Further analysis revealed miR-377 to directly target the $3^{\prime}$ UTR region of HDAC9 mRNA transcripts [142]. Wei, D. et al. (2019) explored the functional role of miR-199a-5p in oral cancer initiation and progression. The findings reported that the overexpression of miR-199a-5p inhibited cell migration and cell invasion, and blocked the epithelial-mesenchymal transition (EMT) cascade [117]. miR-655 is known to suppress invasion along with abrogating proliferation in oral squamous cell 
carcinoma by targeting metadherin [160]. Lu, L. et al. (2013) explored the role of miR-29a in oral squamous cell carcinoma, and the results showed that exogenous overexpression of miR-29a inhibited OSCC cell invasion and anti-apoptosis significantly by targeting MMP-2. Moreover, knockdown of miR-29a promoted OSCC cell invasion and induced drug-resistance in vitro [70]. MiR-205-5p was found to suppress the invasiveness of oral squamous cell carcinoma by inhibiting tissue inhibitor of metalloproteinase 2 (TIMP2) expression. The results also suggested that TIMP2 promotes tumor progression and miR205-5p directly regulates TIMP2, which leads to suppression of pro-MMP 2 activations and inhibition of OSCC cell invasiveness [126]. In another study, miR-124 was found to suppress oral squamous cell carcinoma motility by targeting integrin subunit beta 1 (ITGB1) [193]. Some miRNAs (miR-1 [53], miR-10b [57], miR-17/20a [59], miR-22 [64], miR23b [66], miR-27 [66], miR-31-5p [76], miR-99a-5p [81], miR-146a-5p [100], miR-155-5p [105], miR-188 [111], miR-195-5p [114], miR-200c-3p [119], miR-216a [129], miR-218-5p [131], miR320 [136], miR-375 [140], miR-450a [147], miR-491-5p [151], miR-495 [153], miR-650 [158]) have been implicated in regulating invasion and migration of oral cancer. Thus, these studies dictate the pivotal role and mechanism of miRNAs in modulating invasion and migration of oral tumor cells in malignancy.

\subsection{Metastasis}

Metastasis is the spread of the primary localized tumor to new positions in the body and is the major cause of cancer-related morbidity worldwide [194,195]. Tumors grow and spread by intricate cross-talk between tumor cells, stromal cells, and its extracellular matrix. As miRNAs behave as genetic switches in the physiological process, they are known to be involved in regulating the reprogramming of molecular events associated with metastasis. One of the studies reported that miR-204-5p could enhance OSCC cell proliferation and metastasis. It was predicted as a regulatory miRNA of CXCR4 in OSCC, and the data analysis strongly indicated a negative correlation between miR-204-5p and CXCR4 expression in OSCC tissues from the patients [123]. A study showed that the levels of miR-497 levels were significantly increased and that of SMAD7 were decreased in OSCC patients' specimens when compared to the adjacent non-tumor tissue. The 5-year survival of the patients with higher miR-497 levels was found to be lower in the surgically resected OSCC samples as compared to healthy controls. In silico analyses showed that miR-497 targeted the 3'-UTR of SMAD7 mRNA to inhibit its translation [154]. Next-generation sequencing for miRNA profiling revealed that miR-21-3p was significantly overexpressed in the OSCC tissues when compared with the corresponding normal tissues. Moreover, high miR-21-3p expression levels were directly correlated with $\mathrm{N}$ classification with a $\mathrm{p}$-value of 0.042 [63]. Another study led to the conclusion that miR-99a repressed oral cancer cell migration and invasion partly through decreasing myotubularin related protein 3 (MTMR3) expression. It also led to the discovery that MTMR3 might serve as a therapeutic target for oral cancer treatment [80]. In another analysis, miR-200c was reported to be downregulated in OSCC tissues when compared with adjacent normal tissues. This showed that miR200c knockdown in the human oral cancer cell line HOC313 significantly suppressed cell invasion and migration, indicating the ability to inhibit tumor progression [118]. In another study, it was analyzed that miR-372 and miR-373 were upregulated in OSCC tissues relative to the control mucosa. Among different clinical variables, overexpression of miR-372 and miR-373 were closely related to nodal metastasis as well as lymphovascular invasion and poor survival. Multivariate analysis showed that both high miR-372 and miR-373 expression were independent predictors for poor survival in OSCC. Further, it was found that miR-372 regulated LATS2 expression in OSCC cell lines [139]. Zhuang et al. (2017) elucidated the functional role of miR-138-5p where it was found to target $\Delta \mathrm{Np} 63$ which increases growth, metastasis, and stem-like properties of OSCC cells, and depletion of $\triangle \mathrm{Np} 63$ greatly represses the OSCC cellular phenotypes in vitro as well as in vivo. It was also found that $\Delta \mathrm{Np} 63$ isoform transcriptionally suppresses the expression of miR138-5p [93]. In another study, it was found that miR-98 inhibits cancer cell growth and 
metastasis by direct targeting IGF1R, implicating miR-98 as a novel potential therapeutic target for OSCC [78]. As shown here, various studies have established miRNAs as essential regulators of metastasis by mediating each step of this transformation.

\subsection{Chemoresistance}

One of the major problems faced by chemotherapeutics for oral cancer is the acquisition of drug resistance causing poor survival outcomes in patients [196,197]. Induction of drug resistance inhibits the apoptosis triggered by the drug leading to increased survival response and proliferation of tumor cells [198]. Recently, miRNAs are associated as essential regulators in the induction of survival responses leading to the acquisition of drug resistance. In one study, exosomes derived from cisplatin-resistant OSCC cells released miR-21 to induce cisplatin resistance in OSCC cells by targeting the phosphatase, tensin homolog, and programmed cell death 4 receptor, as well as led to the decrease in DNA damage signaling response to the cisplatin [199]. The results of another study indicated that STAT3/miR-21 axis could be a plausible therapeutic target for OSCC chemoresistance. It was suggested that STAT3 regulated the OSCC cell survival and confer DNA damage resistance through the upregulation of miR-21 and its subsequent downstream targets, including phosphatase and tensin homolog (PTEN), TIMP3, and PDCD4 [200]. Inhibiting miR-1246 in oral cancer stem cells (OCSC) led to a reduction in the stemness hallmarks of the cells, whereas the overexpression of miR-1246 led to enhancements of these characteristics. Additionally, the downregulation of miR-1246 led to a decrease in chemoresistance in OSCC cell lines. It was verified that miR-1246 inhibited CCNG2 which contributed to the cancer stemness of OSCC [161]. In another study, it was confirmed that miR-654-5p promoted chemoresistance of OSCC in vitro and in vivo. It regulates the OSCC progression, likely, through the GRAP/Ras/Erk signaling pathway suggesting its important role as a potential biomarker for the clinical diagnosis and prognosis of OSCC [159]. Recently, Kirave et al. (2020) established the significance of exosomal-mediated miR-155 shuttling in the cisplatin-induced chemoresistance, commonly observed in OSCC cells. Transfer of extracellular vesicles to the cisplatin sensitive cells from resistant cell lines were found to have a significant increase in miR-155 levels in the recipient sensitive cells. Restoration of miR-155 triggered the epithelial to mesenchymal transition, increased migration potential, and attainment of the resistant phenotype [201]. Thus, these studies indicate the potential of miRNAs in inducing and regulating chemoresistance in oral cancer and their targets could be used to direct the cancer cells to committed stages of cell death.

\subsection{Radio-Resistance and Radiosensitivity}

Various pieces of evidence suggest that oral cancer stem cells (OSCs) possess high tumorigenic and metastatic properties leading to the acquisition of radio-resistance. This in turn leads to disease recurrence and poor clinical outcomes in oral cancer patients. Very few studies have presented miRNAs involvement in radiosensitivity and radio-resistance for oral cancer. Upregulation of miR-494-3p in SAS OSCC cell lines led to an increase in the population of senescence-associated $\beta$-galactosidase positive cells with upregulation of p16INK4a and retinoblastoma 1 (RB1) levels and downregulation of Bmi 1 expression. Thus, the study showed that miR-494-3p could increase the radiosensitivity of OSCC cells through the induction of cellular senescence caused by the downregulation of Bmi 1 [152]. A similar mechanistic study showcased that the andrographolide, derived from the medicinal plant Andrographis, increased the expression of miR-218, resulting in the downregulation of Bmi1, hence reducing the stemness of cancer cells. Thus, the results suggest that andrographolide is a viable natural compound for the treatment of OSCC by increasing the radiosensitivity [202]. The downregulated miR-125b expression was associated with proliferation and radio-resistance mechanisms in OSCC, likely through intercellular Adhesion Molecule 2 (ICAM2) signaling. In another study, the expression of miR-125b was confirmed through real-time quantitative reverse transcriptase-PCR and functional analysis revealed that the activity of miR-125b might contribute to suppressing 
proliferation and overcoming radio-resistance in OSCC [203]. Similarly, in another research, it was demonstrated that miR-375 inhibits growth and enhances radiosensitivity in OSCC cells by targeting IGF-1R. The upregulation of miR-375 caused a significant inhibition in growth, induction of cell cycle arrest in G0/G1 phase, increase in apoptosis, and enhanced radiosensitivity in OSCC cells, overall suggesting that miR-375 may be a potential therapeutic target for OSCC patients [141]. Although few studies potentiate the role of miRNAs in inducing radioresistance in oral cancer, further studies are required to understand the mechanisms and plausible targets to develop a combinatorial therapeutic regimen leading to inhibition of tumor growth.

\section{4. miRNAs as Biomarkers for Oral Cancers}

One of the major causes of morbidity and poor survival of oral cancer patients is the lack of detection at earlier stages [204]. Moreover, the current diagnostic methods, such as oral examination or collection of biopsies, followed by histopathological analysis, pose various drawbacks in terms of tissue heterogenicity, inaccurate stratification, surgical complications leading to painful invasive procedures [205]. Hence, it is imperative to search for non-invasive biomarkers that can detect the tumor at earlier stages and complement the therapeutics to eliminate cancer [206]. miRNAs fit the profile for candidate biomarkers because of their distinct and unique signatures in different cancer types when compared with the adjacent normal [207]. Besides, being in high abundance, most of the miRNAs are secreted in bodily fluids like the serum, saliva, and plasma, which can be convenient for non-invasive diagnostic procedures [208]. Hence the utility of miRNAs as prospective biomarkers should be explored further to establish them as potential biomarkers for the clinical management of this oral malady.

The use of expression profiling to determine the molecular classification of the type of human cancers has recently gained impetus in discovering novel biomarkers for diagnosis and establishing a therapeutic regimen $[209,210]$. Several studies have reported the aberrant deregulation of miRNAs in human cancers, including tumor tissues, serum, plasma, and saliva [211,212]. Some of the relevant candidate miRNAs associated with the deregulation in oral cancers have been listed in Table 2. Wong et al. (2008) was the first to detect the aberrant expression of miRNAs in oral cancer. Microarray analysis revealed the overexpression of miR-184 levels in 20 oral tumor tissues as compared to healthy controls. Moreover, miR-184 was found to be upregulated in plasma and its expression was decreased after surgical resection indicating it as a prognostic factor [213]. Further exploration by the other groups potentiated the role of miR-184 in oral cancer, especially at the surgical tumoral margin site advocating its importance in assessing the minimal disease residue $[214,215]$. Since then, several studies have reported promising miRNAs as biomarkers in different bodily fluids and at the tumor site. A retrospective study indicated the unique signatures of miRNAs from 51 formalin-fixed oral tumor tissues. Upregulation of miR-16, miR-21, miR-423, let-7i, miR-20a, miR-155, miR-106b, and miR-142-3p was observed with concomitant downregulation of miR-375, miR-125b, and miR-10a [216]. Childs et al. (2009) revealed the differential miRNA expressed in oral primary tumor tissues; miR-155, miR-21, miR-221, and miR-191 were found to be overexpressed, whereas let-7d, miR-1, miR-205, and miR-133a were downregulated [217]. Moreover, miR-375 was reported to be under-expressed and $\mathrm{miR}-200 \mathrm{c}$, miR-21, and miR-34a were overexpressed in tumor tissues when compared to the control tissues [218]. In a multi-cohort study involving 54 oral cancer patients, 7 patients suffering precancerous lesion, and 36 healthy individuals, $\mathrm{miR}-10 \mathrm{~b}$ was significantly expressed with receiver operating characteristic (ROC) analysis (area under the curve (AUC) of 0.932 for oral cancer and AUC of 0.967 for precancerous lesions) indicating a high potency for its usage as an oral cancer biomarker [219]. Lamperska et al. (2016) implicated the use of miR-21 and miR-205 to evaluate the clarity in surgical margins of oral tumor tissues, but couldn't correlate the miRNAs with clinical outcomes in patients [220]. 
Table 2. MicroRNAs as diagnostic biomarkers in oral cancer.

\begin{tabular}{|c|c|c|c|}
\hline miRNA & Source & Expression in OSCC & References \\
\hline Let-7b & Serum & High & [221] \\
\hline Let-7d & Serum & Low & [221] \\
\hline $\operatorname{miR}-7$ & Serum & High & [221] \\
\hline $\operatorname{miR}-9$ & Serum & Low & {$[222,223]$} \\
\hline miR-16 & Serum & High & [221] \\
\hline $\operatorname{miR}-16$ & Tissue & High & [216] \\
\hline miR-20a & Tissue & High & [216] \\
\hline miR-21 & Blood & High & [224] \\
\hline $\operatorname{miR}-21-3 p$ & Tissue & High & [225] \\
\hline $\operatorname{miR}-24$ & Blood & High & [226] \\
\hline $\operatorname{miR}-24-3 p$ & Saliva/ECVs & High & [227] \\
\hline miR-25 & Serum & High & [221] \\
\hline miR-26a & Plasma & High & [228] \\
\hline $\operatorname{miR}-27 b$ & Saliva & High & [229] \\
\hline $\operatorname{miR}-29 a$ & Serum & Low & [221] \\
\hline $\operatorname{miR}-29 a$ & Blood & Low & [226] \\
\hline miR-30a-5p & Plasma & High & [230] \\
\hline miR-31 & Saliva & High & [231] \\
\hline $\operatorname{miR}-31-5 p$ & Serum & High & [232] \\
\hline $\operatorname{miR}-96-5 p$ & Tissue & High & [225] \\
\hline miR-99b & Plasma & High & [233] \\
\hline $\operatorname{miR}-125 b$ & Tissue & Low & [216] \\
\hline $\operatorname{miR}-125 b$ & Tissue & Low & [203] \\
\hline miR-130-3p & Tissue & High & [225] \\
\hline miR-141-3p & Tissue & High & [225] \\
\hline miR-142 & Serum & Low & [221] \\
\hline miR-142-3p & Tissue & High & [216] \\
\hline $\operatorname{miR}-144-5 p$ & Plasma & High & [230] \\
\hline miR-146a & Tissue & High & [234] \\
\hline miR-150-5p & Plasma & Low & [221] \\
\hline miR-155 & Blood & High & [235] \\
\hline miR-155 & Tissue & High & [102] \\
\hline miR-181 & Tissue & High & [236] \\
\hline miR-184 & Tissue & High & [213] \\
\hline miR-184 & Serum & High & [237] \\
\hline miR-187-5p & Plasma & High & [238] \\
\hline miR-191 & Blood & High & [235] \\
\hline miR-192-5p & Plasma & Low & [233] \\
\hline miR-194-5p & Plasma & High & [233] \\
\hline miR-195 & Serum & High & [221] \\
\hline miR-196a & Plasma & High & [239] \\
\hline miR-196b & Plasma & High & [239] \\
\hline miR-196a/b & Tissue & High & [240] \\
\hline miR-200b-3p & Plasma & High & [241] \\
\hline miR-205 & Tissue & Low & [217] \\
\hline miR-211 & Tissue & Low & [242] \\
\hline $\operatorname{miR}-212-3 p$ & Plasma & High & [233] \\
\hline miR-214-3p & Plasma & High & [233] \\
\hline miR-223 & Tissue & Low & [133] \\
\hline miR-335-5p & Plasma & High & [233] \\
\hline miR-338 & Serum & Low & [221] \\
\hline miR-370-3p & Plasma & High & [230] \\
\hline $\operatorname{miR}-375$ & Tissue & Low & [216] \\
\hline miR-375 & Plasma & Low & [228] \\
\hline miR-412-3p & Saliva/ECVs & High & [243] \\
\hline miR-483-5p & Serum & High & [149] \\
\hline miR-486-5p & Plasma & Low & [228] \\
\hline $\operatorname{miR}-491-5 p$ & Tissue & Low & [151] \\
\hline miR-494 & Blood & High & [235] \\
\hline $\operatorname{miR}-512-3 p$ & Saliva/ECVs & High & [243] \\
\hline
\end{tabular}


Table 2. Cont.

\begin{tabular}{cccc}
\hline miRNA & Source & Expression in OSCC & References \\
miR-601 & Plasma & Low & {$[233]$} \\
miR-603 & Plasma & High & {$[233]$} \\
miR-624 & Serum & High & {$[221]$} \\
miR-660-5p & Plasma & High & {$[233]$} \\
miR-769-5p & Plasma & High & {$[230]$} \\
miR-1303 & Plasma & High & {$[233]$} \\
miR-3651 & Blood & High & {$[110]$} \\
\hline
\end{tabular}

Recently, studies have advocated the exploration of circulating miRNAs present in bodily fluids like the serum, plasma, or saliva, as it offers non-invasive strategies for ameliorating the survival and quality of life of patients making miRNAs as next-generation diagnostic tools. In a study, miR-24 was found to be significantly overexpressed in plasma of oral cancer patients with a typical ROC curve (AUC) of 0.82 with high sensitivity [244]. Similarly, another study showed a positive correlation between overexpressed miR-24 levels in tumor tissues and the clinical stage [245]. High expression of miR-196a and miR$196 \mathrm{~b}$ was reported in the plasma of OSCC patients. Extensive ROC analysis (AUC of 0.864 and 0.960 ) suggested these miRNAs be unique and specific to oral cancer patients when compared with the healthy controls [239]. Tachibana et al. (2016) identified 20 aberrant and unique miRNAs from a subset of 1211 human miRNA array in gingival squamous cell carcinoma samples. Interestingly, there were wide variations in the levels of miR-223 in the plasma and tissue of patients. miR-223 exhibited high levels in plasma whereas it was downregulated in tumor tissues which could be due to its release in the bloodstream from the tumor site as a defense mechanism to inhibit cancer growth [133]. A study investigated the deregulated and significant miRNAs in 101 oral cancer patients and 103 healthy individuals. A significant increase in miR-483-5p serum levels was observed which could differentiate cancer patients with high sensitivity and specificity of $85 \%$ and $74 \%$ respectively. Moreover, its upregulation in serum was positively correlated with the tumor-node-metastasis (TNM) classification and lymph node metastasis suggesting its plausible importance in the stratification of late and early-stage cancer [149].

A grade-specific increase in expression of miR-200b-3p has been reported in plasma samples of grade II-III tumors when compared with grade I samples. Moreover, the circulating levels of miR-200b-3p were decreased when the tumor was surgically removed. It exhibited high sensitivity $(90 \%)$ and specificity $(88.75 \%)$ in the classification of oral samples from healthy individuals [241]. In another study, miR-187-5p was upregulated in plasma of 63 OSCC patients when compared with 23 healthy samples with an AUC value of 0.73 indicating its high sensitivity [238]. Later, miR-187-5p was associated as an oncogene to increase the proliferation and migration of oral cancer cell lines. A recent study by $\mathrm{Lu}$ and his colleagues explored the selected five miRNAs (miR-31-5p miR-99a$5 p$, miR-21-5p miR-375-3p, and miR-138-5p) based on previous reports and evaluated its expression levels in serum and tissue of oral cancer patients. Increased expression levels of miR-31-5p were observed in both serum and tissue samples, whereas serum levels of miR-375-3p, miR-138-5p, and miR-99a-5p were associated with clinical outcomes [232] Another study investigated the miRNome of cancer and healthy oral mucosa. miRNA-seq platform analyzed the differentially regulated plasma miRNA in 55 OSCC patients and 18 healthy individuals. Notably, four miRNAs (miR-769-5p, miR-370-3p, miR-144-5p, and miR-30a-5p) showed upregulation in plasma samples from cancer patients. Moreover, the ROC analysis using the combinational approach of two miRNAs, miR-370-3p and miR-30a-5p resulted in an AUC value of one suggesting it as a potential biomarker in oral cancer diagnosis [230].

Genome-wide expression analysis of human saliva samples revealed distinct miRNA signatures when compared with healthy controls. Upregulation of miR-24 and miR-27b with decreased expression of miR-125a, miR-125a, miR-1250, miR-668, miR-136, miR-148a, 
miR-323-5p, miR-147, miR-200a, miR-503, miR-646, miR-877, miR-632, and miR-220a was observed in saliva of OSCC patients [246,247]. Further studies with miR-27b associated its expression with oral lichen planus, a precancerous lesion, and patients with OSCC recurrence [229]. Gai et al. (2018) first reported the profile of salivary miRNAs present in tumor-derived extracellular vesicles (ECVs). The study revealed miR-517b-3p and miR-320-3p as unique miRNAs present in ECVs and increased levels of miR-512-3 and miR-412-3p in oral tissues with AUC values of 0.847 and 0.87 , respectively [243]. A phase I observational clinical trials with 360 participants are recruiting to investigate the clinical utility of serum derived miRNAs unique signatures in high-risk oral precancerous lesions (ClinicalTrials.gov Identifier: NCT03202810). Another clinical trial is ongoing to explore the prognostic value of miR-29b in 100 oral cancer patients. Blood and saliva samples will be collected over the period of the study and patient specific information with lifestyle factors will be taken into consideration in this trial (ClinicalTrials.gov Identifier: NCT02009852). In one of the Phase III interventional and randomized clinical trials, 62 participants will be treated with metformin hydrochloride and their miRNA signatures will be evaluated for establishing them as disease monitoring tools (ClinicalTrials.gov Identifier: NCT03685409). These findings suggest miRNAs as plausible candidates to be used in the development of novel diagnostic tools leading to the circumventing of oral tumorigenesis.

\section{5. miRNAs as a Therapeutic Approach for Oral Cancer}

Though the recent development of drugs and therapeutic strategies have capacitated improvements in the diagnosis and treatment of oral cancer, the fact that the OSCC is the most common cause of cancer-related death in head and neck cancers worldwide prompts an urgent need for novel and more efficacious therapies [33]. Accumulating evidence on the role of miRNAs in the development and regulation of oral cancers emphasizes the potential of it being used as a therapeutic target [248]. With the advancement of newer forms of technology, such as synthetic biology and nanotechnology, several RNA-guided medicines are being developed and are extensively investigated [26,249]. The most alluring attribute of using miRNA-based therapeutics is its silencing of genes in advanced stages of cancer with utility in cancer detection at any stage. In addition to its specificity, targeting multiple genes in pathways responsible for tumor progression is also an added benefit [250]. The miRNA-based silencing approach has achieved lots of attention in cancer therapeutics due to its fast, economical, and site-specific delivery parameters. The in vitro experimental data shows promising results but optimization needs to be done for onsite delivery of this drug in humans [251]. The main obstacles to achieving gene silencing in vivo arise due to the instability of the RNA molecule, its low transfection efficiency, and distribution in the target tissue [252]. Apart from these limitations, cross-talk with the differential feedback loops, pleiotropic effects of genes, heterogeneity of the tumor, and reoccurrence of the tumor after therapy are other challenges to onsite delivery of these small RNA molecules [253]. A plethora of literature indicated the application of using anti-miRs or miRNA mimics as a novel therapeutic approach, as these molecules can manipulate miRNA expression and function when delivered locally or systemically [254,255]. The identification of crucial miRNAs with oncogenic or tumor-suppressive roles in OSCC has given a newer strategy for their application in OSCC therapy.

Various in vitro and in vivo investigations have indicated the potential of miRNAs to suppress various tumorigenic hallmarks of oral cancers. In one of the studies, miR-381-3p mimics when transduced into SCC-9 and Tca-8113 cell lines, resulting in the downregulation of FGFR2 leading to inhibition of proliferation and migration [143]. Another study demonstrated that overexpression of miR-205 downregulated ZEB1, ZEB2, and N-cadherin, and upregulated E-cadherin leading to reduced migratory and invasive attributes of oral cancer cells [256]. Overexpression of miR-375 upregulated SCC-4 cell radiation-induced apoptosis by regulation of IGF1R [141]. Fu et al. (2017) demonstrated that downregulation of miR-155 leads to overexpression of CDKN1B, which in turn inhibited cell proliferation and cell cycle progression in oral cancer Tca8113 cells [179]. A study revealed that cells 
transfected with miR-373-3p mimics exhibited downregulation in E-cadherin and CK18 levels with concomitant upregulation in N-cadherin expression [257]. Jiang et al. (2014) showed that decreased levels of miR-222, induced chemosensitivity of oral cancer cells to cisplatin (CDDP) and suggested a combination of anti-miR-222 and CDDP may result in overexpression of p53, which regulates apoptosis could be a novel targeting approach [258]. Another study found that miR-205 targets the IL-24 promoter directly and induces gene expression. Thus, miR-205 has a great therapeutic potential to turn on silenced tumor suppressor genes [125]. Later, the same group also established that miR-205 suppresses the oral carcinoma oncogenic activity via downregulation of Axin-2 in the KB human oral cancer cell [124]. It was reported that miR-16 functions as a tumor-suppressor gene in oral squamous cell carcinoma by targeting AKT3 and BCL2L2 [58]. Another study observed that miR-125b suppresses oral oncogenicity by targeting the anti-oxidative gene PRXL2A [87]. A study of miR-181a showed its tumor-suppressive effect against oral squamous cell carcinoma cells by downregulating K-ras expression levels [106]. In another study, it was found that miR-338 suppresses the growth and metastasis of OSCC cells by targeting NRP1 [137]. $\mathrm{miR}-199 \mathrm{a} 5 \mathrm{p}$ was found to function as a tumor suppressor in oral squamous cell carcinoma via targeting the inhibitor of nuclear factor kappa-B kinase subunit beta (IKK $\beta$ )/NF- $к B$ signaling pathway [117], which is quite interesting as IKK $\beta / N F-\kappa B$ has generally been reported to promote tumorigenesis [259-262]. An analysis of miR-186 indicated it as a tumor suppressor in oral squamous cell carcinoma by negatively regulating the protein tyrosine phosphatase SHP2 expression [109]. Though a number of Phase I clinical trials with systemically administered miRNA molecules conjugated with different delivery vehicles are already complete for other chronic diseases, further clinical studies are imperative to establish these new therapeutic efficacies in successfully and safely inhibiting targeted gene products in patients with oral cancer.

\section{Conclusions}

It is now evident that miRNAs play a pivotal role in regulating different hallmarks of oral tumorigenesis, such as proliferation, apoptosis, invasion, migration, and metastasis. Moreover, recent research associate miRNA aberrant signatures in modulating chemoresistance and radioresistance in oral cancer. miRNA regulatory network should be considered as an intricate cross talk between the target mRNA and miRNA leading to post transcriptional inactivation. The emergence of new miRNA knowledge and its potential role in the cancer creates a new understanding of cell transformation. Hence, it is necessary to further study about the different roles of miRNAs, which can contribute to early diagnosis, targeted therapy, and prognosis evaluation of oral cancer patients. Though cancer-related miRNome repertoire is ever-increasing, there exists a large-scale variation among the results of different studies. These variations could be due to change in study design, population size, use of relevant controls (either adjacent normal or healthy control), methodology, pool size, tumor heterogenicity, variability in ethio-physiology. Careful and logical selection, along with functional characterization of miRNAs, is very crucial for understanding the dynamics of miRNA regulation. Standardized and randomized validation research must be undertaken to ensure the sensitivity, specificity, and robustness of the miRNA studies for tailoring individual patient conditions leading to development of personalized therapeutic regimen. Thus, it is necessary to do well-designed, multi-centered trials with large patient groups, to mitigate external variations in data sets. This will provide useful and accurate information for development of novel diagnostics and pave the way for more detailed and precise studies on miRNAs and OSCC in general. Identifying basal threshold levels or combining differentially expressed miRNAs could pave the way for development of early diagnostic and prognostic tools. Many possibilities present for miRNA in oral cancers include targeting genes that appear to be mediators in cancer progression, discovering novel biomarkers for early diagnosis, identifying molecular targets, and engineering delivery vehicles conjugated with DNA as therapeutic devices; thus, representing the ideal theranostic approach. A better understanding of the putative miRNA targets through 
in silico pathway and validation analysis would open up different perspectives for more refined and effective therapeutic regimens combating oral cancer.

Funding: This research received no external funding.

Acknowledgments: This research was funded by the Department of Biotechnology (DBT), Government of India, BT/BI/14/042/2017 dated 12-07-2018 (DAICENTER) awarded to Ajaikumar B. Kunnumakkara. The work was supported by a grant from the Singapore Ministry of Education Tier 2 (MOE-000071-00) to Alan Prem Kumar. Alan Prem Kumar is also supported by the National Medical Research Council of Singapore and the Singapore Ministry of Education under its Research Centre of Excellence initiative to the Cancer Science Institute of Singapore, National University of Singapore.

Conflicts of Interest: The authors declare no conflict of interest

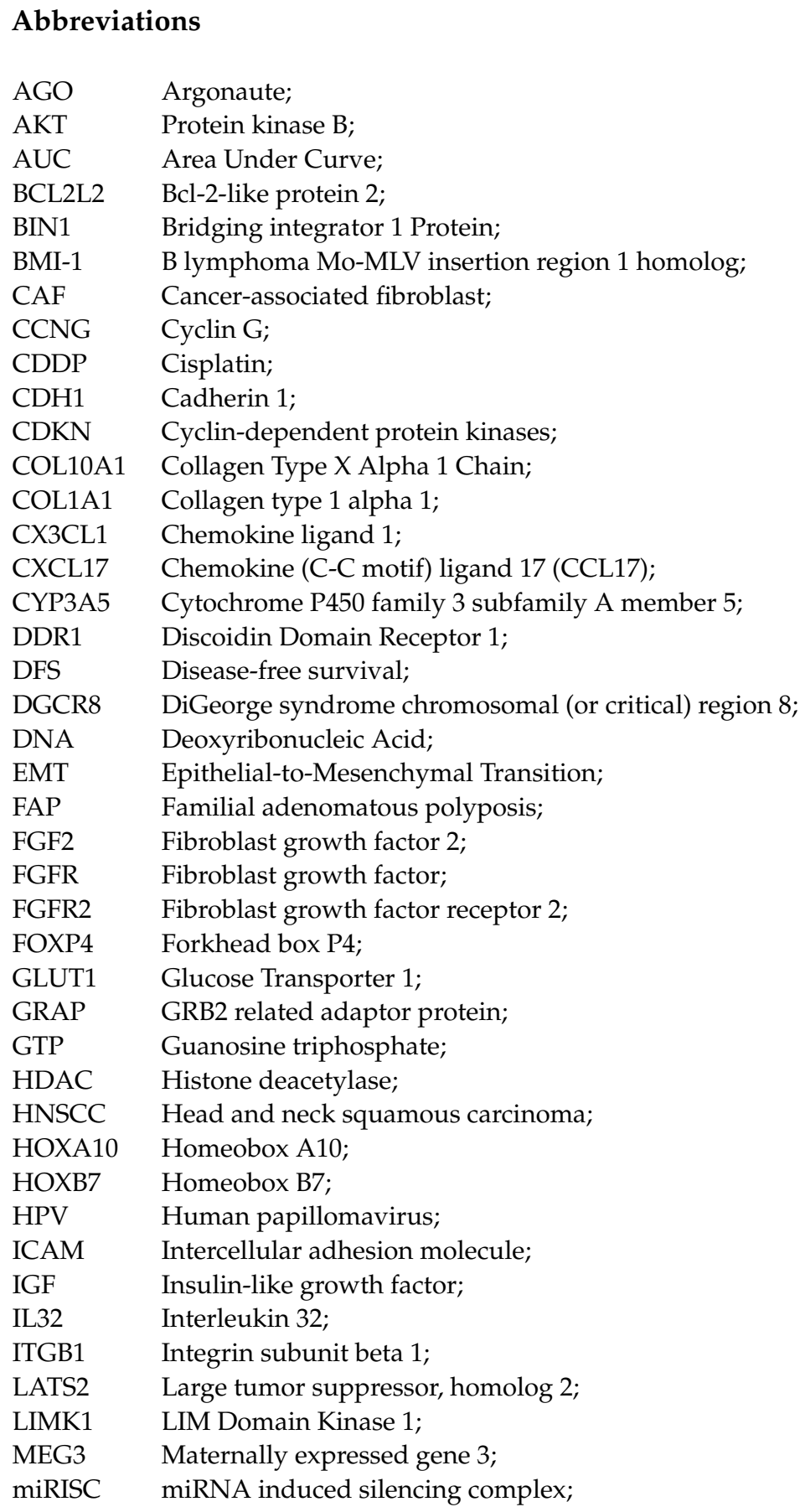




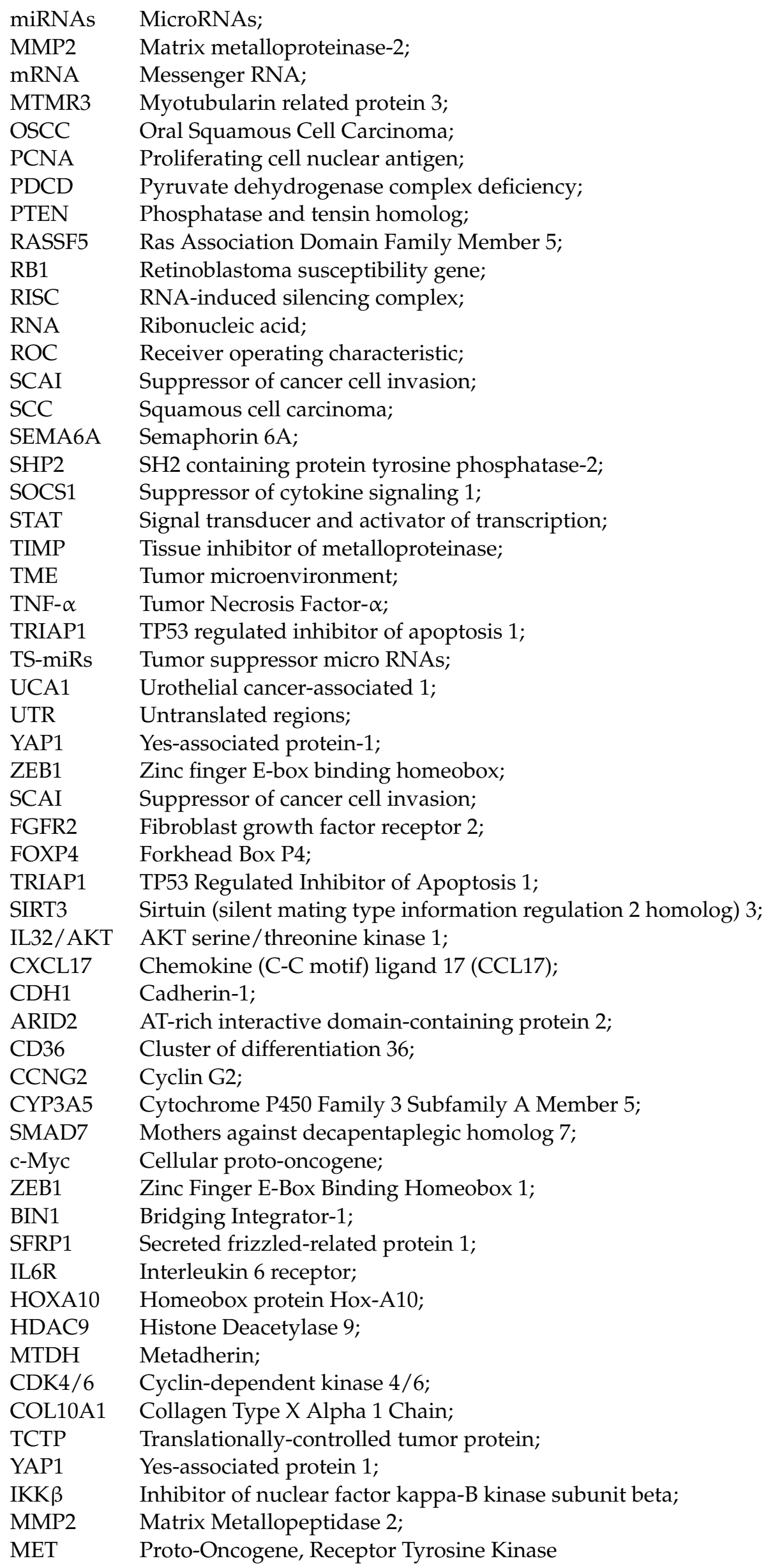




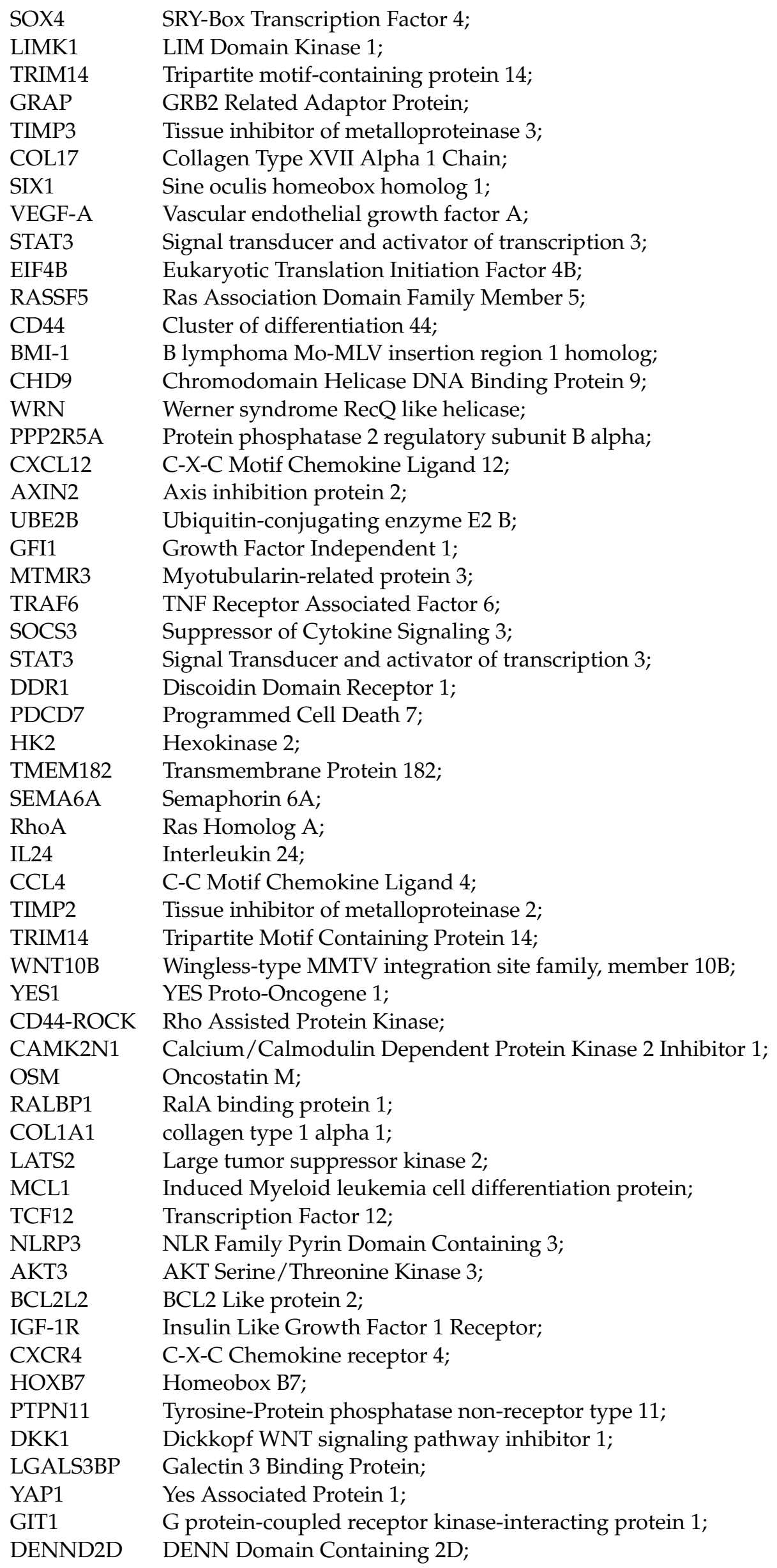




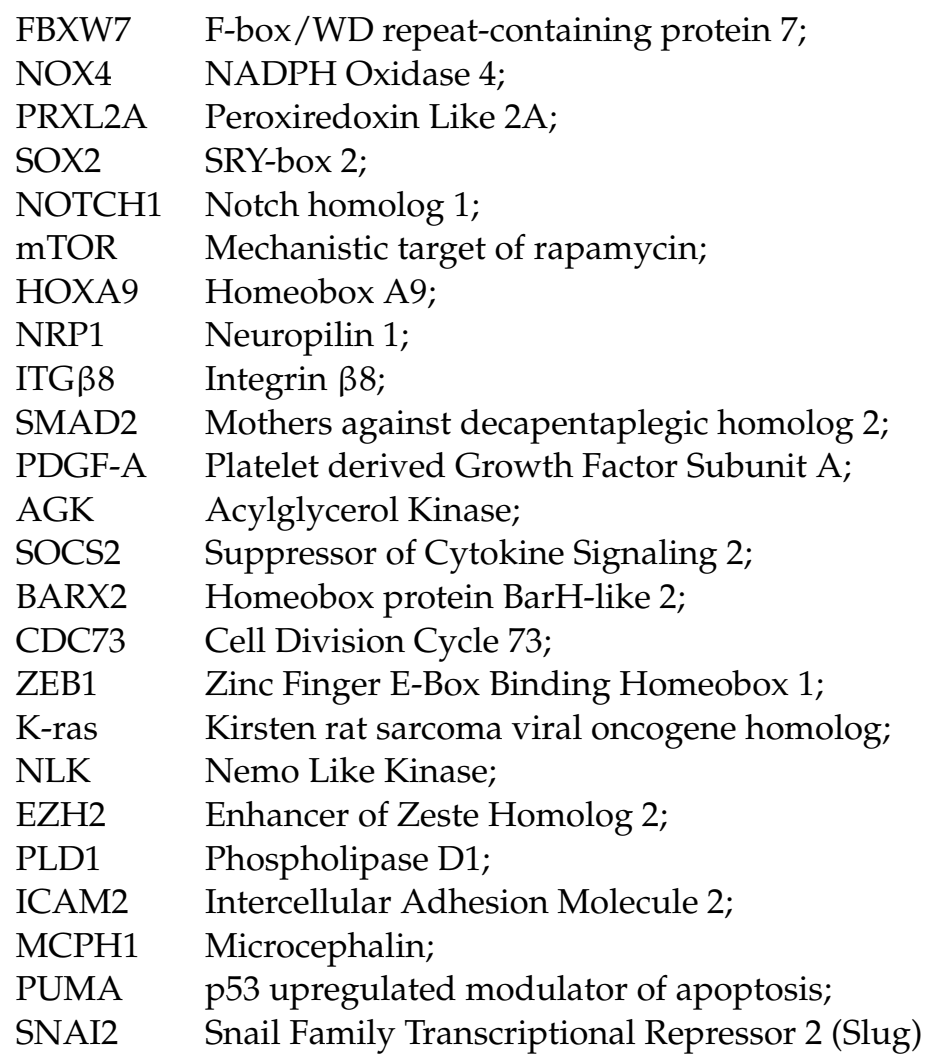

\section{References}

1. Vigneswaran, N.; Williams, M.D. Epidemiologic trends in head and neck cancer and aids in diagnosis. Oral Maxillofac. Surg. Clin. N. Am. 2014, 26, 123-141. [CrossRef]

2. Canning, M.; Guo, G.; Yu, M.; Myint, C.; Groves, M.W.; Byrd, J.K.; Cui, Y. Heterogeneity of the Head and Neck Squamous Cell Carcinoma Immune Landscape and Its Impact on Immunotherapy. Front. Cell Dev. Biol. 2019, 7, 52. [CrossRef]

3. Montero, P.H.; Patel, S.G. Cancer of the oral cavity. Surg. Oncol. Clin. N. Am. 2015, 24, 491-508. [CrossRef] [PubMed]

4. Neville, B.W.; Day, T.A. Oral cancer and precancerous lesions. CA Cancer J. Clin. 2002, 52, 195-215. [CrossRef] [PubMed]

5. Blandin Knight, S.; Crosbie, P.A.; Balata, H.; Chudziak, J.; Hussell, T.; Dive, C. Progress and prospects of early detection in lung cancer. Open Biol. 2017, 7, 170070. [CrossRef]

6. Monisha, J.; Roy, N.K.; Padmavathi, G.; Banik, K.; Bordoloi, D.; Khwairakpam, A.D.; Arfuso, F.; Chinnathambi, A.; Alahmadi, T.A.; Alharbi, S.A.; et al. NGAL is downregulated in oral squamous cell carcinoma and leads to increased survival, proliferation, migration and chemoresistance. Cancers 2018, 10, 228. [CrossRef]

7. Behera, A.K.; Kumar, M.; Shanmugam, M.K.; Bhattacharya, A.; Rao, V.J.; Bhat, A.; Vasudevan, M.; Gopinath, K.S.; Mohiyuddin, A.; Chatterjee, A.; et al. Functional interplay between YY1 and CARM1 promotes oral carcinogenesis. Oncotarget 2019, 10, 3709-3724. [CrossRef]

8. Mello, F.W.; Melo, G.; Pasetto, J.J.; Silva, C.A.B.; Warnakulasuriya, S.; Rivero, E.R.C. The synergistic effect of tobacco and alcohol consumption on oral squamous cell carcinoma: A systematic review and meta-analysis. Clin. Oral Investig. 2019, 23, 2849-2859. [CrossRef]

9. Hernandez, B.Y.; Zhu, X.; Goodman, M.T.; Gatewood, R.; Mendiola, P.; Quinata, K.; Paulino, Y.C. Betel nut chewing, oral premalignant lesions, and the oral microbiome. PLoS ONE 2017, 12, e0172196. [CrossRef] [PubMed]

10. Chen, P.C.; Kuo, C.; Pan, C.C.; Chou, M.Y. Risk of oral cancer associated with human papillomavirus infection, betel quid chewing, and cigarette smoking in Taiwan-An integrated molecular and epidemiological study of 58 cases. J. Oral Pathol. Med. Off. Publ. Int. Assoc. Oral Pathol. Am. Acad. Oral Pathol. 2002, 31, 317-322. [CrossRef]

11. Sathiyasekar, A.C.; Chandrasekar, P.; Pakash, A.; Kumar, K.U.; Jaishlal, M.S. Overview of immunology of oral squamous cell carcinoma. J. Pharm. Bioallied Sci. 2016, 8 (Suppl. S1), S8-S12. [CrossRef]

12. Sinha, N.; Panda, P.K.; Naik, P.P.; Das, D.N.; Mukhopadhyay, S.; Maiti, T.K.; Shanmugam, M.K.; Chinnathambi, A.; Zayed, M.E.; Alharbi, S.A.; et al. Abrus agglutinin promotes irreparable DNA damage by triggering ROS generation followed by ATM-p73 mediated apoptosis in oral squamous cell carcinoma. Mol. Carcinog. 2017, 56, 2400-2413. [CrossRef] [PubMed]

13. Huang, S.H.; O'Sullivan, B. Oral cancer: Current role of radiotherapy and chemotherapy. Med. Oral Patol. Oral Cir. Bucal 2013, 18, e233-e240. [CrossRef] [PubMed]

14. Sim, Y.C.; Hwang, J.H.; Ahn, K.M. Overall and disease-specific survival outcomes following primary surgery for oral squamous cell carcinoma: Analysis of consecutive 67 patients. J. Korean Assoc. Oral Maxillofac. Surg. 2019, 45, 83-90. [CrossRef] [PubMed] 
15. Day, T.A.; Davis, B.K.; Gillespie, M.B.; Joe, J.K.; Kibbey, M.; Martin-Harris, B.; Neville, B.; Reed, S.G.; Richardson, M.S.; Rosenzweig, S.; et al. Oral cancer treatment. Curr. Treat. Options Oncol. 2003, 4, 27-41. [CrossRef] [PubMed]

16. Baek, S.H.; Ko, J.H.; Lee, H.; Jung, J.; Kong, M.; Lee, J.W.; Lee, J.; Chinnathambi, A.; Zayed, M.E.; Alharbi, S.A.; et al. Resveratrol inhibits STAT3 signaling pathway through the induction of SOCS-1: Role in apoptosis induction and radiosensitization in head and neck tumor cells. Phytomed. Int. J. Phytother. Phytopharm. 2016, 23, 566-577. [CrossRef] [PubMed]

17. Aalto, A.P.; Pasquinelli, A.E. Small non-coding RNAs mount a silent revolution in gene expression. Curr. Opin. Cell Biol. 2012, 24, 333-340. [CrossRef]

18. Lim, L.P.; Lau, N.C.; Weinstein, E.G.; Abdelhakim, A.; Yekta, S.; Rhoades, M.W.; Burge, C.B.; Bartel, D.P. The microRNAs of Caenorhabditis elegans. Genes Dev. 2003, 17, 991-1008. [CrossRef] [PubMed]

19. Frixa, T.; Donzelli, S.; Blandino, G. Oncogenic MicroRNAs: Key players in malignant transformation. Cancers 2015, 7, 2466-2485. [CrossRef]

20. Chamorro Petronacci, C.M.; Pérez-Sayáns, M.; Padín Iruegas, M.E.; Suárez Peñaranda, J.M.; Lorenzo Pouso, A.I.; Blanco Carrión, A.; García García, A. miRNAs expression of oral squamous cell carcinoma patients: Validation of two putative biomarkers. Medicine 2019, 98, e14922. [CrossRef]

21. Li, M.; Marin-Muller, C.; Bharadwaj, U.; Chow, K.H.; Yao, Q.; Chen, C. MicroRNAs: Control and loss of control in human physiology and disease. World J. Surg. 2009, 33, 667-684. [CrossRef] [PubMed]

22. Ashrafizadeh, M.; Zarrabi, A.; Hushmandi, K.; Kalantari, M.; Mohammadinejad, R.; Javaheri, T.; Sethi, G. Association of the Epithelial-Mesenchymal Transition (EMT) with cisplatin resistance. Int. J. Mol. Sci. 2020, 21, 4002. [CrossRef]

23. Ashrafizadeh, M.; Hushmandi, K.; Hashemi, M.; Akbari, M.E.; Kubatka, P.; Raei, M.; Koklesova, L.; Shahinozzaman, M.; Mohammadinejad, R.; Najafi, M.; et al. Role of microRNA/Epithelial-to-Mesenchymal transition axis in the metastasis of bladder cancer. Biomolecules 2020, 10, 1159. [CrossRef]

24. Catalanotto, C.; Cogoni, C.; Zardo, G. MicroRNA in control of gene expression: An overview of nuclear functions. Int. J. Mol. Sci. 2016, 17, 1712. [CrossRef]

25. Martin, H.C.; Wani, S.; Steptoe, A.L.; Krishnan, K.; Nones, K.; Nourbakhsh, E.; Vlassov, A.; Grimmond, S.M.; Cloonan, N. Imperfect centered miRNA binding sites are common and can mediate repression of target mRNAs. Genome Biol. 2014, 15, R51. [CrossRef]

26. Iorio, M.V.; Croce, C.M. MicroRNA dysregulation in cancer: Diagnostics, monitoring and therapeutics. A comprehensive review. EMBO Mol. Med. 2017, 9, 852. [CrossRef] [PubMed]

27. Si, W.; Shen, J.; Zheng, H.; Fan, W. The role and mechanisms of action of microRNAs in cancer drug resistance. Clin. Epigenetics 2019, 11, 25. [CrossRef] [PubMed]

28. He, W.; Xu, J.; Huang, Z.; Zhang, J.; Dong, L. MiRNAs in cancer therapy: Focusing on their bi-directional roles. ExRNA 2019, 1, 7. [CrossRef]

29. Baranwal, S.; Alahari, S.K. miRNA control of tumor cell invasion and metastasis. Int. J. Cancer 2010, 126, 1283-1290. [CrossRef] [PubMed]

30. Svoronos, A.A.; Engelman, D.M.; Slack, F.J. Oncomir or tumor suppressor? The duplicity of MicroRNAs in cancer. Cancer Res. 2016, 76, 3666-3670. [CrossRef] [PubMed]

31. Manikandan, M.; Deva Magendhra Rao, A.K.; Arunkumar, G.; Manickavasagam, M.; Rajkumar, K.S.; Rajaraman, R.; Munirajan, A.K. Oral squamous cell carcinoma: MicroRNA expression profiling and integrative analyses for elucidation of tumourigenesis mechanism. Mol. Cancer 2016, 15, 28. [CrossRef]

32. Manasa, V.G.; Kannan, S. Impact of microRNA dynamics on cancer hallmarks: An oral cancer scenario. Tumour Biol. J. Int. Soc. Oncodev. Biol. Med. 2017, 39, 1010428317695920. [CrossRef]

33. Fang, C.; Li, Y. Prospective applications of microRNAs in oral cancer. Oncol. Lett. 2019, 18, 3974-3984. [CrossRef] [PubMed]

34. Alles, J.; Fehlmann, T.; Fischer, U.; Backes, C.; Galata, V.; Minet, M.; Hart, M.; Abu-Halima, M.; Grässer, F.A.; Lenhof, H.P.; et al. An estimate of the total number of true human miRNAs. Nucleic Acids Res. 2019, 47, 3353-3364. [CrossRef]

35. Wang, H.; Peng, R.; Wang, J.; Qin, Z.; Xue, L. Circulating microRNAs as potential cancer biomarkers: The advantage and disadvantage. Clin. Epigenet. 2018, 10, 59. [CrossRef]

36. Condrat, C.E.; Thompson, D.C.; Barbu, M.G.; Bugnar, O.L.; Boboc, A.; Cretoiu, D.; Suciu, N.; Cretoiu, S.M.; Voinea, S.C. miRNAs as biomarkers in disease: Latest findings regarding their role in diagnosis and prognosis. Cells 2020, 9, 276. [CrossRef] [PubMed]

37. Ling, H.; Fabbri, M.; Calin, G.A. MicroRNAs and other non-coding RNAs as targets for anticancer drug development. Nat. Rev. Drug Discov. 2013, 12, 847-865. [CrossRef] [PubMed]

38. Olena, A.F.; Patton, J.G. Genomic organization of microRNAs. J. Cell. Physiol. 2010, 222, 540-545. [CrossRef]

39. Ramalingam, P.; Palanichamy, J.K.; Singh, A.; Das, P.; Bhagat, M.; Kassab, M.A.; Sinha, S.; Chattopadhyay, P. Biogenesis of intronic miRNAs located in clusters by independent transcription and alternative splicing. RNA 2014, 20, 76-87. [CrossRef] [PubMed]

40. Peng, Y.; Croce, C.M. The role of MicroRNAs in human cancer. Signal Transduct. Target. Ther. 2016, 1, 15004. [CrossRef]

41. Macfarlane, L.A.; Murphy, P.R. MicroRNA: Biogenesis, function and role in cancer. Current Genom. 2010, 11, 537-561. [CrossRef]

42. O'Brien, J.; Hayder, H.; Zayed, Y.; Peng, C. Overview of MicroRNA biogenesis, mechanisms of actions, and circulation. Front. Endocrinol. 2018, 9, 402. [CrossRef]

43. Han, J.; Lee, Y.; Yeom, K.H.; Kim, Y.K.; Jin, H.; Kim, V.N. The Drosha-DGCR8 complex in primary microRNA processing. Genes Dev. 2004, 18, 3016-3027. [CrossRef] 
44. Wang, X.; Xu, X.; Ma, Z.; Huo, Y.; Xiao, Z.; Li, Y.; Wang, Y. Dynamic mechanisms for pre-miRNA binding and export by Exportin-5. RNA 2011, 17, 1511-1528. [CrossRef] [PubMed]

45. Chong, M.M.; Zhang, G.; Cheloufi, S.; Neubert, T.A.; Hannon, G.J.; Littman, D.R. Canonical and alternate functions of the microRNA biogenesis machinery. Genes Dev. 2010, 24, 1951-1960. [CrossRef] [PubMed]

46. Westholm, J.O.; Lai, E.C. Mirtrons: MicroRNA biogenesis via splicing. Biochimie 2011, 93, 1897-1904. [CrossRef]

47. Havens, M.A.; Reich, A.A.; Duelli, D.M.; Hastings, M.L. Biogenesis of mammalian microRNAs by a non-canonical processing pathway. Nucleic Acids Res. 2012, 40, 4626-4640. [CrossRef]

48. Miyoshi, K.; Miyoshi, T.; Siomi, H. Many ways to generate microRNA-like small RNAs: Non-canonical pathways for microRNA production. Mol. Genet. Genom. 2010, 284, 95-103. [CrossRef]

49. Liu, H.; Lei, C.; He, Q.; Pan, Z.; Xiao, D.; Tao, Y. Nuclear functions of mammalian MicroRNAs in gene regulation, immunity and cancer. Mol. Cancer 2018, 17, 64. [CrossRef] [PubMed]

50. Slezak-Prochazka, I.; Durmus, S.; Kroesen, B.J.; van den Berg, A. MicroRNAs, macrocontrol: Regulation of miRNA processing. RNA 2010, 16, 1087-1095. [CrossRef] [PubMed]

51. Politz, J.C.; Zhang, F.; Pederson, T. MicroRNA-206 colocalizes with ribosome-rich regions in both the nucleolus and cytoplasm of rat myogenic cells. Proc. Natl. Acad. Sci. USA 2006, 103, 18957-18962. [CrossRef]

52. Passetti, F.; Ferreira, C.G.; Costa, F.F. The impact of microRNAs and alternative splicing in pharmacogenomics. Pharm. J. 2009, 9, 1-13. [CrossRef]

53. Peng, C.Y.; Liao, Y.W.; Lu, M.Y.; Yu, C.H.; Yu, C.C.; Chou, M.Y. Downregulation of miR-1 enhances tumorigenicity and invasiveness in oral squamous cell carcinomas. J. Formos. Med. Assoc. 2017, 116, 782-789. [CrossRef]

54. Wang, Z.; Wang, J.; Chen, Z.; Wang, K.; Shi, L. MicroRNA-1-3p inhibits the proliferation and migration of oral squamous cell carcinoma cells by targeting DKK1. Biochem. Cell Biol. Biochim. Biol. Cell. 2018, 96, 355-364. [CrossRef] [PubMed]

55. Shang, A.; Lu, W.Y.; Yang, M.; Zhou, C.; Zhang, H.; Cai, Z.X.; Wang, W.W.; Wang, W.X.; Wu, G.Q. miR-9 induces cell arrest and apoptosis of oral squamous cell carcinoma via CDK 4/6 pathway. Artif. Cells Nanomed. Biotechnol. 2018, 46, 1754-1762. [CrossRef]

56. Chen, Y.H.; Song, Y.; Yu, Y.L.; Cheng, W.; Tong, X. miRNA-10a promotes cancer cell proliferation in oral squamous cell carcinoma by upregulating GLUT1 and promoting glucose metabolism. Oncol. Lett. 2019, 17, 5441-5446. [CrossRef] [PubMed]

57. Lu, Y.C.; Chen, Y.J.; Wang, H.M.; Tsai, C.Y.; Chen, W.H.; Huang, Y.C.; Fan, K.H.; Tsai, C.N.; Huang, S.F.; Kang, C.J.; et al. Oncogenic function and early detection potential of miRNA-10b in oral cancer as identified by microRNA profiling. Cancer Prev. Res. 2012, 5, 665-674. [CrossRef]

58. Wang, X.; Li, G.H. MicroRNA-16 functions as a tumor-suppressor gene in oral squamous cell carcinoma by targeting AKT3 and BCL2L2. J. Cell. Physiol. 2018, 233, 9447-9457. [CrossRef] [PubMed]

59. Chang, C.C.; Yang, Y.J.; Li, Y.J.; Chen, S.T.; Lin, B.R.; Wu, T.S.; Lin, S.K.; Kuo, M.Y.; Tan, C.T. MicroRNA-17/20a functions to inhibit cell migration and can be used a prognostic marker in oral squamous cell carcinoma. Oral Oncol. 2013, 49, 923-931. [CrossRef] [PubMed]

60. Huang, C.; Song, H.; Lai, L. The role and mechanism of microRNA-18a-5p in oral squamous cell carcinoma. Mol. Med. Rep. 2019, 20, 1637-1644. [CrossRef]

61. Qiu, Y.F.; Wang, M.X.; Meng, L.N.; Zhang, R.; Wang, W. MiR-21 regulates proliferation and apoptosis of oral cancer cells through TNF- $\alpha$. Eur. Rev. Med. Pharmacol. Sci. 2018, 22, 7735-7741. [CrossRef] [PubMed]

62. Mahmood, N.; Hanif, M.; Ahmed, A.; Jamal, Q.; Mushtaq, S.; Khan, A.; Saqib, M. Circulating miR-21 as a prognostic and predictive biomarker in oral squamous cell carcinoma. Pak. J. Med. Sci. 2019, 35, 1408-1412. [CrossRef]

63. Tseng, H.H.; Tseng, Y.K.; You, J.J.; Kang, B.H.; Wang, T.H.; Yang, C.M.; Chen, H.C.; Liou, H.H.; Liu, P.F.; Ger, L.P.; et al. Nextgeneration sequencing for microRNA profiling: MicroRNA-21-3p promotes oral cancer metastasis. AntiCancer Res. 2017, 37, 1059-1066. [CrossRef] [PubMed]

64. Feng, X.; Luo, Q.; Wang, H.; Zhang, H.; Chen, F. MicroRNA-22 suppresses cell proliferation, migration and invasion in oral squamous cell carcinoma by targeting NLRP3. J. Cell. Physiol. 2018, 233, 6705-6713. [CrossRef]

65. Chen, F.; Qi, S.; Zhang, X.; Wu, J.; Yang, X.; Wang, R. miR-23a-3p suppresses cell proliferation in oral squamous cell carcinomas by targeting FGF2 and correlates with a better prognosis: miR-23a-3p inhibits OSCC growth by targeting FGF2. Pathol. Res. Pract. 2019, 215, 660-667. [CrossRef]

66. Fukumoto, I.; Koshizuka, K.; Hanazawa, T.; Kikkawa, N.; Matsushita, R.; Kurozumi, A.; Kato, M.; Okato, A.; Okamoto, Y.; Seki, N. The tumor-suppressive microRNA-23b/27b cluster regulates the MET oncogene in oral squamous cell carcinoma. Int. J. Oncol. 2016, 49, 1119-1129. [CrossRef]

67. Wang, F.; Xu, J.; Liu, H.; Liu, Z.; Xia, F. Metformin induces apoptosis by microRNA-26a-mediated downregulation of myeloid cell leukaemia-1 in human oral cancer cells. Mol. Med. Rep. 2016, 13, 4671-4676. [CrossRef]

68. Zeng, G.; Xun, W.; Wei, K.; Yang, Y.; Shen, H. MicroRNA-27a-3p regulates epithelial to mesenchymal transition via targeting YAP1 in oral squamous cell carcinoma cells. Oncol. Rep. 2016, 36, 1475-1482. [CrossRef]

69. Lo, W.Y.; Wang, H.J.; Chiu, C.W.; Chen, S.F. miR-27b-regulated TCTP as a novel plasma biomarker for oral cancer: From quantitative proteomics to post-transcriptional study. J. Proteom. 2012, 77, 154-166. [CrossRef]

70. Lu, L.; Xue, X.; Lan, J.; Gao, Y.; Xiong, Z.; Zhang, H.; Jiang, W.; Song, W.; Zhi, Q. MicroRNA-29a upregulates MMP2 in oral squamous cell carcinoma to promote cancer invasion and anti-apoptosis. Biomed. Pharmacother. Biomed. Pharmacother. 2014, 68, 13-19. [CrossRef] [PubMed] 
71. Yang, C.N.; Deng, Y.T.; Tang, J.Y.; Cheng, S.J.; Chen, S.T.; Li, Y.J.; Wu, T.S.; Yang, M.H.; Lin, B.R.; Kuo, M.Y.; et al. MicroRNA-29b regulates migration in oral squamous cell carcinoma and its clinical significance. Oral Oncol. 2015, 51, 170-177. [CrossRef]

72. He, J.; Ye, W.; Kou, N.; Chen, K.; Cui, B.; Zhang, X.; Hu, S.; Liu, T.; Kang, L.; Li, X. MicroRNA-29b-3p suppresses oral squamous cell carcinoma cell migration and invasion via IL32/AKT signalling pathway. J. Cell. Mol. Med. 2020, 24, 841-849. [CrossRef]

73. Kurihara-Shimomura, M.; Sasahira, T.; Shimomura, H.; Nakashima, C.; Kirita, T. The oncogenic activity of miR-29b-1-5p induces the epithelial-mesenchymal transition in oral squamous cell carcinoma. J. Clin. Med. 2019, 8, 273. [CrossRef] [PubMed]

74. Chattopadhyay, E.; Singh, R.; Ray, A.; Roy, R.; De Sarkar, N.; Paul, R.R.; Pal, M.; Aich, R.; Roy, B. Expression deregulation of mir31 and CXCL12 in two types of oral precancers and cancer: Importance in progression of precancer and cancer. Sci. Rep. 2016, 6, 32735. [CrossRef] [PubMed]

75. Kao, Y.Y.; Chou, C.H.; Yeh, L.Y.; Chen, Y.F.; Chang, K.W.; Liu, C.J.; Fan Chiang, C.Y.; Lin, S.C. MicroRNA miR-31 targets SIRT3 to disrupt mitochondrial activity and increase oxidative stress in oral carcinoma. Cancer Lett. 2019, 456, 40-48. [CrossRef]

76. Lai, Y.H.; Liu, H.; Chiang, W.F.; Chen, T.W.; Chu, L.J.; Yu, J.S.; Chen, S.J.; Chen, H.C.; Tan, B.C. MiR-31-5p-ACOX1 axis enhances tumorigenic fitness in oral squamous cell carcinoma via the promigratory prostaglandin E2. Theranostics 2018, 8, 486-504 [CrossRef] [PubMed]

77. Li, T.; Li, L.; Li, D.; Wang, S.; Sun, J. MiR-34a inhibits oral cancer progression partially by repression of interleukin-6-receptor. Int. J. Clin. Exp. Pathol. 2015, 8, 1364-1373.

78. Du, Y.; Li, Y.; Lv, H.; Zhou, S.; Sun, Z.; Wang, M. miR-98 suppresses tumor cell growth and metastasis by targeting IGF1R in oral squamous cell carcinoma. Int. J. Clin. Exp. Pathol. 2015, 8, 12252-12259.

79. Yan, B.; Fu, Q.; Lai, L.; Tao, X.; Fei, Y.; Shen, J.; Chen, Z.; Wang, Q. Downregulation of microRNA 99a in oral squamous cell carcinomas contributes to the growth and survival of oral cancer cells. Mol. Med. Rep. 2012, 6, 675-681. [CrossRef]

80. Kuo, Y.Z.; Tai, Y.H.; Lo, H.I.; Chen, Y.L.; Cheng, H.C.; Fang, W.Y.; Lin, S.H.; Yang, C.L.; Tsai, S.T.; Wu, L.W. MiR-99a exerts anti-metastasis through inhibiting myotubularin-related protein 3 expression in oral cancer. Oral Dis. 2014, 20, e65-e75. [CrossRef]

81. Shi, Y.; Bo, Z.; Pang, G.; Qu, X.; Bao, W.; Yang, L.; Ma, Y. MiR-99a-5p regulates proliferation, migration and invasion abilities of human oral carcinoma cells by targeting NOX4. Neoplasma 2017, 64, 666-673. [CrossRef] [PubMed]

82. Wu, B.; Lei, D.; Wang, L.; Yang, X.; Jia, S.; Yang, Z.; Shan, C.; Yang, X.; Zhang, C.; Lu, B. MiRNA-101 inhibits oral squamous-cell carcinoma growth and metastasis by targeting zinc finger E-box binding homeobox 1. Am. J. Cancer Res. 2016, 6, 1396-1407.

83. Xie, C.; Du, L.Y.; Guo, F.; Li, X.; Cheng, B. Exosomes derived from microRNA-101-3p-overexpressing human bone marrow mesenchymal stem cells suppress oral cancer cell proliferation, invasion, and migration. Mol. Cell. Biochem. 2019, 458, 11-26. [CrossRef]

84. Shi, B.; Ma, C.; Liu, G.; Guo, Y. MiR-106a directly targets LIMK1 to inhibit proliferation and EMT of oral carcinoma cells. Cell. Mol. Biol. Lett. 2019, 24, 1. [CrossRef]

85. Na, C.; Li, X.; Zhang, J.; Han, L.; Li, Y.; Zhang, H. miR-107 targets TRIAP1 to regulate oral squamous cell carcinoma proliferation and migration. Int. J. Clin. Exp. Pathol. 2019, 12, 1820-1825.

86. Li, X.; Fan, Q.; Li, J.; Song, J.; Gu, Y. MiR-124 down-regulation is critical for cancer associated fibroblasts-enhanced tumor growth of oral carcinoma. Exp. Cell Res. 2017, 351, 100-108. [CrossRef]

87. Chen, Y.F.; Wei, Y.Y.; Yang, C.C.; Liu, C.J.; Yeh, L.Y.; Chou, C.H.; Chang, K.W.; Lin, S.C. miR-125b suppresses oral oncogenicity by targeting the anti-oxidative gene PRXL2A. Redox Biol. 2019, 22, 101140. [CrossRef] [PubMed]

88. Sasahira, T.; Kurihara, M.; Bhawal, U.K.; Ueda, N.; Shimomoto, T.; Yamamoto, K.; Kirita, T.; Kuniyasu, H. Downregulation of miR-126 induces angiogenesis and lymphangiogenesis by activation of VEGF-A in oral cancer. Br. J. Cancer 2012, 107, 700-706. [CrossRef] [PubMed]

89. He, B.; Lin, X.; Tian, F.; Yu, W.; Qiao, B. MiR-133a-3p Inhibits Oral Squamous Cell Carcinoma (OSCC) proliferation and invasion by suppressing COL1A1. J. Cell. Biochem. 2018, 119, 338-346. [CrossRef] [PubMed]

90. Peng, S.Y.; Tu, H.F.; Yang, C.C.; Wu, C.H.; Liu, C.J.; Chang, K.W.; Lin, S.C. miR-134 targets PDCD7 to reduce E-cadherin expression and enhance oral cancer progression. Int. J. Cancer 2018, 143, 2892-2904. [CrossRef] [PubMed]

91. Zeng, D.; Xu, H.; Ji, N.; Li, J.; Zhou, M.; Dan, H.; Zhou, Y.; Zeng, X.; Jiang, L.; Chen, Q. In situ measurement of miR-138 expression in oral squamous cell carcinoma tissue supports the role of this microRNA as a tumor suppressor. J. Oral Pathol. Med. Off. Publ. Int. Assoc. Oral Pathol. Acad. Oral Pathol. 2019, 48, 911-918. [CrossRef]

92. Xu, R.; Zeng, G.; Gao, J.; Ren, Y.; Zhang, Z.; Zhang, Q.; Zhao, J.; Tao, H.; Li, D. miR-138 suppresses the proliferation of oral squamous cell carcinoma cells by targeting Yes-associated protein 1. Oncol. Rep. 2015, 34, 2171-2178. [CrossRef]

93. Zhuang, Z.; Xie, N.; Hu, J.; Yu, P.; Wang, C.; Hu, X.; Han, X.; Hou, J.; Huang, H.; Liu, X. Interplay between $\Delta$ Np63 and miR-138-5p regulates growth, metastasis and stemness of oral squamous cell carcinoma. Oncotarget 2017, 8, 21954-21973. [CrossRef]

94. Ren, Y.; Zhu, H.; Chi, C.; Yang, F.; Xu, X. MiRNA-139 regulates oral cancer Tca8113 cells apoptosis through Akt signaling pathway. Int. J. Clin. Exp. Pathol. 2015, 8, 4588-4594.

95. Wang, K.; Jin, J.; Ma, T.; Zhai, H. MiR-139-5p inhibits the tumorigenesis and progression of oral squamous carcinoma cells by targeting HOXA9. J. Cell. Mol. Med. 2017, 21, 3730-3740. [CrossRef]

96. Sun, X.; Zhang, L. MicroRNA-143 suppresses oral squamous cell carcinoma cell growth, invasion and glucose metabolism through targeting hexokinase 2. Biosci. Rep. 2017, 37, BSR20160404. [CrossRef] [PubMed]

97. Shao, Y.; Qu, Y.; Dang, S.; Yao, B.; Ji, M. MiR-145 inhibits oral squamous cell carcinoma (OSCC) cell growth by targeting c-Myc and Cdk6. Cancer Cell Int. 2013, 13, 51. [CrossRef] [PubMed] 
98. Moon, S.; Kim, D.K.; Kim, J. Apoptosis-related microRNA-145-5p enhances the effects of pheophorbide a-based photodynamic therapy in oral cancer. Oncotarget 2017, 8, 35184-35192. [CrossRef] [PubMed]

99. Shi, Z.; Johnson, J.J.; Jiang, R.; Liu, Y.; Stack, M.S. Decrease of miR-146a is associated with the aggressiveness of human oral squamous cell carcinoma. Arch. Oral Biol. 2015, 60, 1416-1427. [CrossRef]

100. Min, S.K.; Jung, S.Y.; Kang, H.K.; Park, S.A.; Lee, J.H.; Kim, M.J.; Min, B.M. Functional diversity of miR-146a-5p and TRAF6 in normal and oral cancer cells. Int. J. Oncol. 2017, 51, 1541-1552. [CrossRef] [PubMed]

101. Ieong, C.; Ma, J.; Lai, W. RALBP1 regulates oral cancer cells via Akt and is a novel target of miR-148a-3p and miR-148b-3p. J. Oral Pathol. Med. Off. Publ. Int. Assoc. Oral Pathol. Am. Acad. Oral Pathol. 2019, 48, 919-928. [CrossRef]

102. Shi, L.J.; Zhang, C.Y.; Zhou, Z.T.; Ma, J.Y.; Liu, Y.; Bao, Z.X.; Jiang, W.W. MicroRNA-155 in oral squamous cell carcinoma: Overexpression, localization, and prognostic potential. Head Neck 2015, 37, 970-976. [CrossRef]

103. Rather, M.I.; Nagashri, M.N.; Swamy, S.S.; Gopinath, K.S.; Kumar, A. Oncogenic microRNA-155 down-regulates tumor suppressor CDC73 and promotes oral squamous cell carcinoma cell proliferation: Implications for cancer therapeutics. J. Biol. Chem. 2013, 288, 608-618. [CrossRef]

104. Kim, H.; Yang, J.M.; Ahn, S.H.; Jeong, W.J.; Chung, J.H.; Paik, J.H. Potential oncogenic role and prognostic implication of MicroRNA-155-5p in oral squamous cell carcinoma. AntiCancer Res. 2018, 38, 5193-5200. [CrossRef] [PubMed]

105. Wu, M.; Duan, Q.; Liu, X.; Zhang, P.; Fu, Y.; Zhang, Z.; Liu, L.; Cheng, J.; Jiang, H. MiR-155-5p promotes oral cancer progression by targeting chromatin remodeling gene ARID2. Biomed. Pharmacother. Biomed. Pharmacother. 2020, 122, 109696. [CrossRef] [PubMed]

106. Shin, K.H.; Bae, S.D.; Hong, H.S.; Kim, R.H.; Kang, M.K.; Park, N.H. miR-181a shows tumor suppressive effect against oral squamous cell carcinoma cells by downregulating K-ras. Biochem. Biophys. Res. Commun. 2011, 404, 896-902. [CrossRef] [PubMed]

107. Li, N.; Nan, C.C.; Zhong, X.Y.; Weng, J.Q.; Fan, H.D.; Sun, H.P.; Tang, S.; Shi, L.; Huang, S.X. miR-182-5p promotes growth in oral squamous cell carcinoma by inhibiting CAMK2N1. Cell. Physiol. Biochem. Int. J. Exp. Cell. Physiol. Biochem. Pharmacol. 2018, 49, 1329-1341. [CrossRef]

108. Fang, Z.; Zhao, J.; Xie, W.; Sun, Q.; Wang, H.; Qiao, B. LncRNA UCA1 promotes proliferation and cisplatin resistance of oral squamous cell carcinoma by sunppressing miR-184 expression. Cancer Med. 2017, 6, 2897-2908. [CrossRef]

109. Cai, Z.; Hao, X.Y.; Liu, F.X. MicroRNA-186 serves as a tumor suppressor in oral squamous cell carcinoma by negatively regulating the protein tyrosine phosphatase SHP2 expression. Arch. Oral Biol. 2018, 89, 20-25. [CrossRef]

110. Ries, J.; Vairaktaris, E.; Agaimy, A.; Kintopp, R.; Baran, C.; Neukam, F.W.; Nkenke, E. miR-186, miR-3651 and miR-494: Potential biomarkers for oral squamous cell carcinoma extracted from whole blood. Oncol. Rep. 2014, 31, 1429-1436. [CrossRef]

111. Wang, L.; Liu, H. microRNA-188 is downregulated in oral squamous cell carcinoma and inhibits proliferation and invasion by targeting SIX1. Tumour Biol. J. Int. Soc. Oncodev. Biol. Med. 2016, 37, 4105-4113. [CrossRef]

112. Chi, H. miR-194 regulated AGK and inhibited cell proliferation of oral squamous cell carcinoma by reducing PI3K-Akt-FoxO3a signaling. Biomed. Pharmacother. Biomed. Pharmacother. 2015, 71, 53-57. [CrossRef]

113. Lien, M.Y.; Tsai, H.C.; Chang, A.C.; Tsai, M.H.; Hua, C.H.; Wang, S.W.; Tang, C.H. Chemokine CCL4 induces vascular endothelial growth factor C expression and lymphangiogenesis by miR-195-3p in oral squamous cell carcinoma. Front. Immunol. 2018, 9, 412. [CrossRef]

114. Wang, T.; Ren, Y.; Liu, R.; Ma, J.; Shi, Y.; Zhang, L.; Bu, R. miR-195-5p suppresses the proliferation, migration, and invasion of oral squamous cell carcinoma by targeting TRIM14. BioMed Res. Int. 2017, 2017, 7378148. [CrossRef]

115. Hou, Y.Y.; You, J.J.; Yang, C.M.; Pan, H.W.; Chen, H.C.; Lee, J.H.; Lin, Y.S.; Liou, H.H.; Liu, P.F.; Chi, C.C.; et al. Aberrant DNA hypomethylation of miR-196b contributes to migration and invasion of oral cancer. Oncol. Lett. 2016, 11, 4013-4021. [CrossRef] [PubMed]

116. Wei, D.; Wang, W.; Shen, B.; Zhou, Y.; Yang, X.; Lu, G.; Yang, J.; Shao, Y. MicroRNA-199a-5p suppresses migration and invasion in oral squamous cell carcinoma through inhibiting the EMT-related transcription factor SOX4. Int. J. Mol. Med. 2019, 44, 185-195. [CrossRef] [PubMed]

117. Wei, D.; Shen, B.; Wang, W.; Zhou, Y.; Yang, X.; Lu, G.; Yang, J.; Shao, Y. MicroRNA-199a-5p functions as a tumor suppressor in oral squamous cell carcinoma via targeting the IKK $\beta / N F-\kappa B$ signaling pathway. Int. J. Mol. Med. 2019, 43, 1585-1596. [CrossRef] [PubMed]

118. Xie, N.N.; Liu, Z.X.; Wu, C.; Wang, P.L.; Song, G.T.; Chen, Z. MicroRNA-200c suppresses tumor metastasis in oral squamous carcinoma by inhibiting epithelial-mesenchymal transition. Eur. Rev. Med Pharmacol. Sci. 2018, 22, 3415-3422. [CrossRef] [PubMed]

119. Kawakubo-Yasukochi, T.; Morioka, M.; Hazekawa, M.; Yasukochi, A.; Nishinakagawa, T.; Ono, K.; Kawano, S.; Nakamura, S.; Nakashima, M. miR-200c-3p spreads invasive capacity in human oral squamous cell carcinoma microenvironment. Mol. Carcinog. 2018, 57, 295-302. [CrossRef] [PubMed]

120. Lee, S.A.; Kim, J.S.; Park, S.Y.; Kim, H.J.; Yu, S.K.; Kim, C.S.; Chun, H.S.; Kim, J.; Park, J.T.; Go, D.; et al. miR-203 downregulates Yes-1 and suppresses oncogenic activity in human oral cancer cells. J. Biosci. Bioeng. 2015, 120, 351-358. [CrossRef] [PubMed]

121. Kim, J.S.; Choi, D.W.; Kim, C.S.; Yu, S.K.; Kim, H.J.; Go, D.S.; Lee, S.A.; Moon, S.M.; Kim, S.G.; Chun, H.S.; et al. MicroRNA-203 induces apoptosis by targeting Bmi-1 in YD-38 oral cancer cells. AntiCancer Res. 2018, 38, 3477-3485. [CrossRef] [PubMed]

122. Lim, H.S.; Kim, C.S.; Kim, J.S.; Yu, S.K.; Go, D.S.; Lee, S.A.; Moon, S.M.; Chun, H.S.; Kim, S.G.; Kim, D.K. Suppression of oral carcinoma oncogenic activity by microRNA-203 via down-regulation of SEMA6A. AntiCancer Res. 2017, 37, 5425-5433. [CrossRef] [PubMed] 
123. Wang, X.; Li, F.; Zhou, X. miR-204-5p regulates cell proliferation and metastasis through inhibiting CXCR4 expression in OSCC. Biomed. Pharmacother. Biomed. Pharmacother. 2016, 82, 202-207. [CrossRef] [PubMed]

124. Kim, J.S.; Park, S.Y.; Lee, S.A.; Park, M.G.; Yu, S.K.; Lee, M.H.; Park, M.R.; Kim, S.G.; Oh, J.S.; Lee, S.Y.; et al. MicroRNA-205 suppresses the oral carcinoma oncogenic activity via down-regulation of Axin-2 in KB human oral cancer cell. Mol. Cell. Biochem. 2014, 387, 71-79. [CrossRef] [PubMed]

125. Kim, J.S.; Yu, S.K.; Lee, M.H.; Park, M.G.; Park, E.; Kim, S.G.; Lee, S.Y.; Kim, C.S.; Kim, H.J.; Chun, H.S.; et al. MicroRNA-205 directly regulates the tumor suppressor, interleukin-24, in human KB oral cancer cells. Mol. Cells 2013, 35, 17-24. [CrossRef]

126. Nagai, H.; Hasegawa, S.; Uchida, F.; Terabe, T.; Ishibashi Kanno, N.; Kato, K.; Yamagata, K.; Sakai, S.; Kawashiri, S.; Sato, H.; et al. MicroRNA-205-5p suppresses the invasiveness of oral squamous cell carcinoma by inhibiting TIMP-2 expression. Int. J. Oncol. 2018, 52, 841-850. [CrossRef]

127. Zheng, J.; Wang, J.; Jia, Y.; Liu, T.; Duan, Y.; Liang, X.; Liu, L. microRNA-211 promotes proliferation, migration, and invasion ability of oral squamous cell carcinoma cells via targeting the bridging integrator 1 protein. J. Cell. Biochem. 2019, 120, 4644-4653. [CrossRef]

128. Li, T.K.; Yin, K.; Chen, Z.; Bao, Y.; Zhang, S.X. MiR-214 regulates oral cancer KB cell apoptosis through targeting RASSF5. Genet. Mol. Res. 2017, 16. [CrossRef]

129. Li, L.; Ma, H.Q. MicroRNA-216a inhibits the growth and metastasis of oral squamous cell carcinoma by targeting eukaryotic translation initiation factor 4B. Mol. Med. Rep. 2015, 12, 3156-3162. [CrossRef] [PubMed]

130. Zhuang, Z.; Hu, F.; Hu, J.; Wang, C.; Hou, J.; Yu, Z.; Wang, T.T.; Liu, X.; Huang, H. MicroRNA-218 promotes cisplatin resistance in oral cancer via the PPP2R5A/Wnt signaling pathway. Oncol. Rep. 2017, 38, 2051-2061. [CrossRef] [PubMed]

131. Li, X.; He, J.; Shao, M.; Cui, B.; Peng, F.; Li, J.; Ran, Y.; Jin, D.; Kong, J.; Chang, J.; et al. Downregulation of miR-218-5p promotes invasion of oral squamous cell carcinoma cells via activation of CD44-ROCK signaling. Biomed. Pharmacother. Biomed. Pharmacother. 2018, 106, 646-654. [CrossRef]

132. Chen, D.; Yan, W.; Liu, Z.; Zhang, Z.; Zhu, L.; Liu, W.; Ding, X.; Wang, A.; Chen, Y. Downregulation of miR-221 enhances the sensitivity of human oral squamous cell carcinoma cells to Adriamycin through upregulation of TIMP3 expression. Biomed. Pharmacother. Biomed. Pharmacother. 2016, 77, 72-78. [CrossRef] [PubMed]

133. Tachibana, H.; Sho, R.; Takeda, Y.; Zhang, X.; Yoshida, Y.; Narimatsu, H.; Otani, K.; Ishikawa, S.; Fukao, A.; Asao, H.; et al. Circulating miR-223 in oral cancer: Its potential as a novel diagnostic biomarker and therapeutic target. PLoS ONE 2016, 11, e0159693. [CrossRef] [PubMed]

134. Jiang, L.; Lv, L.; Liu, X.; Jiang, X.; Yin, Q.; Hao, Y.; Xiao, L. MiR-223 promotes oral squamous cell carcinoma proliferation and migration by regulating FBXW7. Cancer Biomark. Sect. A Dis. Markers 2019, 24, 325-334. [CrossRef]

135. Xu, Y.; Liu, Y.; Xiao, W.; Yue, J.; Xue, L.; Guan, Q.; Deng, J.; Sun, J. MicroRNA-299-3p/FOXP4 axis regulates the proliferation and migration of oral squamous cell carcinoma. Technol. Cancer Res. Treat. 2019, 18, 1533033819874803. [CrossRef] [PubMed]

136. Wu, Y.Y.; Chen, Y.L.; Jao, Y.C.; Hsieh, I.S.; Chang, K.C.; Hong, T.M. miR-320 regulates tumor angiogenesis driven by vascular endothelial cells in oral cancer by silencing neuropilin 1. Angiogenesis 2014, 17, 247-260. [CrossRef]

137. Liu, C.; Wang, Z.; Wang, Y.; Gu, W. MiR-338 suppresses the growth and metastasis of OSCC cells by targeting NRP1. Mol. Cell. Biochem. 2015, 398, 115-122. [CrossRef] [PubMed]

138. Xu, P.; Li, Y.; Zhang, H.; Li, M.; Zhu, H. MicroRNA-340 mediates metabolic shift in oral squamous cell carcinoma by targeting glucose transporter-1. J. Oral Maxillofac. Surg. Off. J. Am. Assoc. Oral Maxillofac. Surg. 2016, 74, 844-850. [CrossRef]

139. Tu, H.F.; Chang, K.W.; Cheng, H.W.; Liu, C.J. Upregulation of miR-372 and -373 associates with lymph node metastasis and poor prognosis of oral carcinomas. Laryngoscope 2015, 125, E365-E370. [CrossRef]

140. Cao, Z.H.; Cheng, J.L.; Zhang, Y.; Bo, C.X.; Li, Y.L. MicroRNA-375 inhibits oral squamous cell carcinoma cell migration and invasion by targeting platelet-derived growth factor-A. Mol. Med. Rep. 2017, 15, 922-928. [CrossRef] [PubMed]

141. Zhang, B.; Li, Y.; Hou, D.; Shi, Q.; Yang, S.; Li, Q. MicroRNA-375 inhibits growth and enhances radiosensitivity in oral squamous cell carcinoma by targeting insulin like growth factor 1 receptor. Cell. Physiol. Biochem. Int. J. Exp. Cell. Physiol. Biochem. Pharmacol. 2017, 42, 2105-2117. [CrossRef]

142. Rastogi, B.; Kumar, A.; Raut, S.K.; Panda, N.K.; Rattan, V.; Joshi, N.; Khullar, M. Downregulation of miR-377 promotes oral squamous cell carcinoma growth and migration by targeting HDAC9. Cancer Investig. 2017, 35, 152-162. [CrossRef]

143. Yang, X.; Ruan, H.; Hu, X.; Cao, A.; Song, L. miR-381-3p suppresses the proliferation of oral squamous cell carcinoma cells by directly targeting FGFR2. Am. J. Cancer Res. 2017, 7, 913-922.

144. Sun, L.P.; Xu, K.; Cui, J.; Yuan, D.Y.; Zou, B.; Li, J.; Liu, J.L.; Li, K.Y.; Meng, Z.; Zhang, B. Cancer-associated fibroblast-derived exosomal miR-382-5p promotes the migration and invasion of oral squamous cell carcinoma. Oncol. Rep. 2019, 42, 1319-1328. [CrossRef] [PubMed]

145. Peng, H.Y.; Jiang, S.S.; Hsiao, J.R.; Hsiao, M.; Hsu, Y.M.; Wu, G.H.; Chang, W.M.; Chang, J.Y.; Jin, S.L.; Shiah, S.G. IL-8 induces miR-424-5p expression and modulates SOCS2/STAT5 signaling pathway in oral squamous cell carcinoma. Mol. Oncol. 2016, 10, 895-909. [CrossRef] [PubMed]

146. Lei, W.; Liu, Y.E.; Zheng, Y.; Qu, L. MiR-429 inhibits oral squamous cell carcinoma growth by targeting ZEB1. Med Sci. Monit. Int. Med J. Exp. Clin. Res. 2015, 21, 383-389. [CrossRef]

147. Hsing, E.W.; Shiah, S.G.; Peng, H.Y.; Chen, Y.W.; Chuu, C.P.; Hsiao, J.R.; Lyu, P.C.; Chang, J.Y. TNF- $\alpha$-induced miR-450a mediates TMEM182 expression to promote oral squamous cell carcinoma motility. PLoS ONE 2019, 14, e0213463. [CrossRef] [PubMed] 
148. Cheng, C.M.; Shiah, S.G.; Huang, C.C.; Hsiao, J.R.; Chang, J.Y. Up-regulation of miR-455-5p by the TGF- $\beta$-SMAD signalling axis promotes the proliferation of oral squamous cancer cells by targeting UBE2B. J. Pathol. 2016, 240, 38-49. [CrossRef]

149. Xu, H.; Yang, Y.; Zhao, H.; Yang, X.; Luo, Y.; Ren, Y.; Liu, W.; Li, N. Serum miR-483-5p: A novel diagnostic and prognostic biomarker for patients with oral squamous cell carcinoma. Tumour Biol. J. Int. Soc. Oncodev. Biol. Med. 2016, 37, 447-453. [CrossRef]

150. Chou, S.T.; Peng, H.Y.; Mo, K.C.; Hsu, Y.M.; Wu, G.H.; Hsiao, J.R.; Lin, S.F.; Wang, H.D.; Shiah, S.G. MicroRNA-486-3p functions as a tumor suppressor in oral cancer by targeting DDR1. J. Exp. Clin. Cancer Res. 2019, 38, 281. [CrossRef]

151. Huang, W.C.; Chan, S.H.; Jang, T.H.; Chang, J.W.; Ko, Y.C.; Yen, T.C.; Chiang, S.L.; Chiang, W.F.; Shieh, T.Y.; Liao, C.T.; et al. miRNA-491-5p and GIT1 serve as modulators and biomarkers for oral squamous cell carcinoma invasion and metastasis. Cancer Res. 2014, 74, 751-764. [CrossRef] [PubMed]

152. Weng, J.H.; Yu, C.C.; Lee, Y.C.; Lin, C.W.; Chang, W.W.; Kuo, Y.L. miR-494-3p induces cellular senescence and enhances radiosensitivity in human oral squamous carcinoma cells. Int. J. Mol. Sci. 2016, 17, 1092. [CrossRef]

153. Lv, L.; Wang, Q.; Yang, Y.; Ji, H. MicroRNA-495 targets Notch1 to prohibit cell proliferation and invasion in oral squamous cell carcinoma. Mol. Med. Rep. 2019, 19, 693-702. [CrossRef]

154. Hu, J.; Xu, J.F.; Ge, W.L. MiR-497 enhances metastasis of oral squamous cell carcinoma through SMAD7 suppression. Am. J. Transl. Res. 2016, 8, 3023-3031. [PubMed]

155. Wang, L.; Chen, W.; Zha, J.; Yan, Y.; Wei, Y.; Chen, X.; Zhu, X.; Ge, L. miR-543 acts as a novel oncogene in oral squamous cell carcinoma by targeting CYP3A5. Oncol. Rep. 2019, 42, 973-990. [CrossRef] [PubMed]

156. Yuan, G.; Wu, H.; Du, Y.; He, F. Tumor suppressor role of microRNA-545 in oral squamous cell carcinoma. Oncol. Lett. 2019, 17, 2063-2068. [CrossRef] [PubMed]

157. Endo, H.; Muramatsu, T.; Furuta, M.; Uzawa, N.; Pimkhaokham, A.; Amagasa, T.; Inazawa, J.; Kozaki, K. Potential of tumorsuppressive miR-596 targeting LGALS3BP as a therapeutic agent in oral cancer. Carcinogenesis 2013, 34, 560-569. [CrossRef]

158. Ningning, S.; Libo, S.; Chuanbin, W.; Haijiang, S.; Qing, Z. MiR-650 regulates the proliferation, migration and invasion of human oral cancer by targeting growth factor independent 1 (Gfi1). Biochimie 2019, 156, 69-78. [CrossRef]

159. Lu, M.; Wang, C.; Chen, W.; Mao, C.; Wang, J. miR-654-5p targets grap to promote proliferation, metastasis, and chemoresistance of oral squamous cell carcinoma through Ras/MAPK Signaling. DNA Cell Biol. 2018, 37, 381-388. [CrossRef]

160. Wang, Q.; Lv, L.; Li, Y.; Ji, H. MicroRNA-655 suppresses cell proliferation and invasion in oral squamous cell carcinoma by directly targeting metadherin and regulating the PTEN/AKT pathway. Mol. Med. Rep. 2018, 18, 3106-3114. [CrossRef]

161. Lin, S.S.; Peng, C.Y.; Liao, Y.W.; Chou, M.Y.; Hsieh, P.L.; Yu, C.C. miR-1246 targets CCNG2 to enhance cancer stemness and chemoresistance in oral carcinomas. Cancers 2018, 10, 272. [CrossRef]

162. Sakha, S.; Muramatsu, T.; Ueda, K.; Inazawa, J. Exosomal microRNA miR-1246 induces cell motility and invasion through the regulation of DENND2D in oral squamous cell carcinoma. Sci. Rep. 2016, 6, 38750. [CrossRef]

163. Liao, L.; Wang, J.; Ouyang, S.; Zhang, P.; Wang, J.; Zhang, M. Expression and clinical significance of microRNA-1246 in human oral squamous cell carcinoma. Med Sci. Monit. Int. Med J. Exp. Clin. Res. 2015, 21, 776-781. [CrossRef]

164. Chen, R.; Zhang, Y.; Zhang, X. MiR-1254 functions as a tumor suppressor in oral squamous cell carcinoma by targeting CD36. Technol. Cancer Res. Treat. 2019, 18, 1533033819859447. [CrossRef]

165. Xu, Y.X.; Sun, J.; Xiao, W.L.; Liu, Y.S.; Yue, J.; Xue, L.F.; Deng, J.; Zhi, K.Q.; Wang, Y.L. MiR-4513 mediates the proliferation and apoptosis of oral squamous cell carcinoma cells via targeting CXCL17. Eur. Rev. Med. Pharmacol. Sci. 2019, 23, 3821-3828. [CrossRef] [PubMed]

166. Wei, Z.; Lyu, B.; Hou, D.; Liu, X. Mir-5100 mediates proliferation, migration and invasion of oral squamous cell carcinoma cells via targeting SCAI. J. Investig. Surg. Off. J. Acad. Surg. Res. 2019, 1-8. [CrossRef] [PubMed]

167. Wu, Y.; Sun, X.; Song, B.; Qiu, X.; Zhao, J. MiR-375/SLC7A11 axis regulates oral squamous cell carcinoma proliferation and invasion. Cancer Med. 2017, 6, 1686-1697. [CrossRef]

168. Libório-Kimura, T.N.; Jung, H.M.; Chan, E.K. miR-494 represses HOXA10 expression and inhibits cell proliferation in oral cancer. Oral Oncol. 2015, 51, 151-157. [CrossRef]

169. Ruan, P.; Tao, Z.; Tan, A. Low expression of miR-30a-5p induced the proliferation and invasion of oral cancer via promoting the expression of FAP. Biosci. Rep. 2018, 38, BSR20171027. [CrossRef] [PubMed]

170. Wang, M.; Qiu, Y.; Zhang, R.; Gao, L.; Wang, X.; Bi, L.; Wang, Y. MEHP promotes the proliferation of oral cancer cells via down regulation of miR-27b-5p and miR-372-5p. Toxicol. Vitr. 2019, 58, 35-41. [CrossRef]

171. Zhivotovsky, B.; Kroemer, G. Apoptosis and genomic instability. Nat. Rev. Mol. Cell Biol. 2004, 5, 752-762. [CrossRef]

172. Hwang, S.T.; Kim, C.; Lee, J.H.; Chinnathambi, A.; Alharbi, S.A.; Shair, O.H.M.; Sethi, G.; Ahn, K.S. Cycloastragenol can negate constitutive STAT3 activation and promote paclitaxel-induced apoptosis in human gastric cancer cells. Phytomed. Int. J. Phytother. Phytopharm. 2019, 59, 152907. [CrossRef] [PubMed]

173. Patra, S.; Praharaj, P.P.; Panigrahi, D.P.; Panda, B.; Bhol, C.S.; Mahapatra, K.K.; Mishra, S.R.; Behera, B.P.; Jena, M.; Sethi, G.; et al. Bioactive compounds from marine invertebrates as potent anticancer drugs: The possible pharmacophores modulating cell death pathways. Mol. Biol. Rep. 2020, 47, 7209-7228. [CrossRef] [PubMed]

174. Kirtonia, A.; Sethi, G.; Garg, M. The multifaceted role of reactive oxygen species in tumorigenesis. Cell. Mol. Life Sci. 2020, 77, 4459-4483. [CrossRef] [PubMed] 
175. Dai, X.; Wang, L.; Deivasigamni, A.; Looi, C.Y.; Karthikeyan, C.; Trivedi, P.; Chinnathambi, A.; Alharbi, S.A.; Arfuso, F.; Dharmarajan, A.; et al. A novel benzimidazole derivative, MBIC inhibits tumor growth and promotes apoptosis via activation of ROS-dependent JNK signaling pathway in hepatocellular carcinoma. Oncotarget 2017, 8, 12831-12842. [CrossRef] [PubMed]

176. Wang, H.; Guo, Y.; Mi, N.; Zhou, L. miR-101-3p and miR-199b-5p promote cell apoptosis in oral cancer by targeting BICC1. Mol. Probes 2020, 52, 101567. [CrossRef] [PubMed]

177. Wang, K.; Jin, J.; Ma, T.; Zhai, H. MiR-376c-3p regulates the proliferation, invasion, migration, cell cycle and apoptosis of human oral squamous cancer cells by suppressing HOXB7. Biomed. Pharmacother. Biomed. Pharmacother. 2017, 91, 517-525. [CrossRef]

178. Tan, J.; Xiang, L.; Xu, G. LncRNA MEG3 suppresses migration and promotes apoptosis by sponging miR-548d-3p to modulate JAK-STAT pathway in oral squamous cell carcinoma. IUBMB Life 2019, 71, 882-890. [CrossRef]

179. Fu, S.; Chen, H.H.; Cheng, P.; Zhang, C.B.; Wu, Y. MiR-155 regulates oral squamous cell carcinoma Tca8113 cell proliferation, cycle, and apoptosis via regulating p27Kip1. Eur. Rev. Med Pharmacol. Sci. 2017, 21, 937-944. [PubMed]

180. Loh, C.Y.; Chai, J.Y.; Tang, T.F.; Wong, W.F.; Sethi, G.; Shanmugam, M.K.; Chong, P.P.; Looi, C.Y. The E-Cadherin and N-Cadherin switch in epithelial-to-mesenchymal transition: Signaling, therapeutic implications, and challenges. Cells 2019, 8, 1118. [CrossRef]

181. Cheng, J.T.; Wang, L.; Wang, H.; Tang, F.R.; Cai, W.Q.; Sethi, G.; Xin, H.W.; Ma, Z. Insights into biological role of LncRNAs in epithelial-mesenchymal transition. Cells 2019, 8, 1178. [CrossRef]

182. Kumar, A.; Golani, A.; Kumar, L.D. EMT in breast cancer metastasis: An interplay of microRNAs, signaling pathways and circulating tumor cells. Front. Biosci. 2020, 25, 979-1010. [CrossRef]

183. Yang, M.H.; Lee, J.H.; Ko, J.H.; Jung, S.H.; Sethi, G.; Ahn, K.S. Brassinin represses invasive potential of lung carcinoma cells through deactivation of PI3K/Akt/mTOR signaling cascade. Molecules 2019, 24, 1584. [CrossRef]

184. Ko, J.H.; Nam, D.; Um, J.Y.; Jung, S.H.; Sethi, G.; Ahn, K.S. Bergamottin suppresses metastasis of lung cancer cells through abrogation of diverse oncogenic signaling cascades and epithelial-to-mesenchymal transition. Molecules 2018, 23, 1601. [CrossRef]

185. Dai, X.; Ahn, K.S.; Wang, L.Z.; Kim, C.; Deivasigamni, A.; Arfuso, F.; Um, J.Y.; Kumar, A.P.; Chang, Y.C.; Kumar, D.; et al. Ascochlorin enhances the sensitivity of doxorubicin leading to the reversal of epithelial-to-mesenchymal transition in hepatocellular carcinoma. Mol. Cancer Ther. 2016, 15, 2966-2976. [CrossRef] [PubMed]

186. Lee, J.H.; Chinnathambi, A.; Alharbi, S.A.; Shair, O.H.M.; Sethi, G.; Ahn, K.S. Farnesol abrogates epithelial to mesenchymal transition process through regulating Akt/mTOR pathway. Pharmacol. Res. 2019, 150, 104504. [CrossRef]

187. Garg, M.; Shanmugam, M.K.; Bhardwaj, V.; Goel, A.; Gupta, R.; Sharma, A.; Baligar, P.; Kumar, A.P.; Goh, B.C.; Wang, L.; et al. The pleiotropic role of transcription factor STAT3 in oncogenesis and its targeting through natural products for cancer prevention and therapy. Med. Res. Rev. 2020. [CrossRef]

188. Kim, C.; Cho, S.K.; Kapoor, S.; Kumar, A.; Vali, S.; Abbasi, T.; Kim, S.H.; Sethi, G.; Ahn, K.S. $\beta$-Caryophyllene oxide inhibits constitutive and inducible STAT3 signaling pathway through induction of the SHP-1 protein tyrosine phosphatase. Mol. Carcinog. 2014, 53, 793-806. [CrossRef] [PubMed]

189. Lee, J.H.; Kim, C.; Sethi, G.; Ahn, K.S. Brassinin inhibits STAT3 signaling pathway through modulation of PIAS-3 and SOCS-3 expression and sensitizes human lung cancer xenograft in nude mice to paclitaxel. Oncotarget 2015, 6, 6386-6405. [CrossRef] [PubMed]

190. Zhang, J.; Ahn, K.S.; Kim, C.; Shanmugam, M.K.; Siveen, K.S.; Arfuso, F.; Samym, R.P.; Deivasigamanim, A.; Lim, L.H.; Wang, L.; et al. Nimbolide-induced oxidative stress abrogates STAT3 signaling cascade and inhibits tumor growth in transgenic adenocarcinoma of mouse prostate model. Antioxid. Redox Signal. 2016, 24, 575-589. [CrossRef] [PubMed]

191. Ko, J.H.; Um, J.Y.; Lee, S.G.; Yang, W.M.; Sethi, G.; Ahn, K.S. Conditioned media from adipocytes promote proliferation, migration, and invasion in melanoma and colorectal cancer cells. J. Cell. Physiol. 2019, 234, 18249-18261. [CrossRef] [PubMed]

192. Shanmugam, M.K.; Ahn, K.S.; Lee, J.H.; Kannaiyan, R.; Mustafa, N.; Manu, K.A.; Siveen, K.S.; Sethi, G.; Chng, W.J.; Kumar, A.P. Celastrol attenuates the invasion and migration and augments the anticancer effects of bortezomib in a xenograft mouse model of multiple myeloma. Front. Pharmacol. 2018, 9, 365. [CrossRef] [PubMed]

193. Hunt, S.; Jones, A.V.; Hinsley, E.E.; Whawell, S.A.; Lambert, D.W. MicroRNA-124 suppresses oral squamous cell carcinoma motility by targeting ITGB1. FEBS Lett. 2011, 585, 187-192. [CrossRef]

194. Shanmugam, M.K.; Ahn, K.S.; Hsu, A.; Woo, C.C.; Yuan, Y.; Tan, K.H.B.; Chinnathambi, A.; Alahmadi, T.A.; Alharbi, S.A.; Koh, A.P.F.; et al. Thymoquinone inhibits bone metastasis of breast cancer cells through abrogation of the CXCR4 signaling axis. Front. Pharmacol. 2018, 9, 1294. [CrossRef]

195. Manu, K.A.; Shanmugam, M.K.; Ong, T.H.; Subramaniam, A.; Siveen, K.S.; Perumal, E.; Samy, R.P.; Bist, P.; Lim, L.H.; Kumar, A.P.; et al. Emodin suppresses migration and invasion through the modulation of CXCR4 expression in an orthotopic model of human hepatocellular carcinoma. PLoS ONE 2013, 8, e57015. [CrossRef] [PubMed]

196. Manu, K.A.; Shanmugam, M.K.; Li, F.; Chen, L.; Siveen, K.S.; Ahn, K.S.; Kumar, A.P.; Sethi, G. Simvastatin sensitizes human gastric cancer xenograft in nude mice to capecitabine by suppressing nuclear factor-kappa B-regulated gene products. J. Mol. Med. 2014, 92, 267-276. [CrossRef] [PubMed]

197. Manu, K.A.; Shanmugam, M.K.; Ramachandran, L.; Li, F.; Siveen, K.S.; Chinnathambi, A.; Zayed, M.E.; Alharbi, S.A.; Arfuso, F.; Kumar, A.P.; et al. Isorhamnetin augments the anti-tumor effect of capecitabine through the negative regulation of NF- $\mathrm{B}$ signaling cascade in gastric cancer. Cancer Lett. 2015, 363, 28-36. [CrossRef] 
198. Chakraborty, S.; Kumar, A.; Faheem, M.M.; Katoch, A.; Kumar, A.; Jamwal, V.L.; Nayak, D.; Golani, A.; Rasool, R.U.; Ahmad, S.M.; et al. Vimentin activation in early apoptotic cancer cells errands survival pathways during DNA damage inducer CPT treatment in colon carcinoma model. Cell Death Dis. 2019, 10, 467. [CrossRef]

199. Liu, T.; Chen, G.; Sun, D.; Lei, M.; Li, Y.; Zhou, C.; Li, X.; Xue, W.; Wang, H.; Liu, C.; et al. Exosomes containing miR-21 transfer the characteristic of cisplatin resistance by targeting PTEN and PDCD4 in oral squamous cell carcinoma. Acta Biochim. Biophys. Sin. 2017, 49, 808-816. [CrossRef]

200. Zhou, X.; Ren, Y.; Liu, A.; Jin, R.; Jiang, Q.; Huang, Y.; Kong, L.; Wang, X.; Zhang, L. WP1066 sensitizes oral squamous cell carcinoma cells to cisplatin by targeting STAT3/miR-21 axis. Sci. Rep. 2014, 4, 7461. [CrossRef]

201. Kirave, P.; Gondaliya, P.; Kulkarni, B.; Rawal, R.; Garg, R.; Jain, A.; Kalia, K. Exosome mediated miR-155 delivery confers cisplatin chemoresistance in oral cancer cells via epithelial-mesenchymal transition. Oncotarget 2020, 11, 1157-1171. [CrossRef] [PubMed]

202. Yang, P.Y.; Hsieh, P.L.; Wang, T.H.; Yu, C.C.; Lu, M.Y.; Liao, Y.W.; Lee, T.H.; Peng, C.Y. Andrographolide impedes cancer stemness and enhances radio-sensitivity in oral carcinomas via miR-218 activation. Oncotarget 2017, 8, 4196-4207. [CrossRef]

203. Shiiba, M.; Shinozuka, K.; Saito, K.; Fushimi, K.; Kasamatsu, A.; Ogawara, K.; Uzawa, K.; Ito, H.; Takiguchi, Y.; Tanzawa, H. MicroRNA-125b regulates proliferation and radioresistance of oral squamous cell carcinoma. Br. J. Cancer 2013, 108, 1817-1821. [CrossRef]

204. van der Waal, I. Are we able to reduce the mortality and morbidity of oral cancer; some considerations. Med. Oral Patol. Oral Cir. Bucal 2013, 18, e33-e37. [CrossRef]

205. Epstein, J.B.; Silverman, S., Jr.; Epstein, J.D.; Lonky, S.A.; Bride, M.A. Analysis of oral lesion biopsies identified and evaluated by visual examination, chemiluminescence and toluidine blue. Oral Oncol. 2008, 44, 538-544. [CrossRef]

206. Konings, H.; Stappers, S.; Geens, M.; De Winter, B.Y.; Lamote, K.; van Meerbeeck, J.P.; Specenier, P.; Vanderveken, O.M.; Ledeganck, K.J. A literature review of the potential diagnostic biomarkers of head and neck neoplasms. Front. Oncol. 2020, 10, 1020. [CrossRef] [PubMed]

207. Ferracin, M.; Pedriali, M.; Veronese, A.; Zagatti, B.; Gafà, R.; Magri, E.; Lunardi, M.; Munerato, G.; Querzoli, G.; Maestri, I.; et al. MicroRNA profiling for the identification of cancers with unknown primary tissue-of-origin. J. Pathol. 2011, $225,43-53$. [CrossRef] [PubMed]

208. Lan, H.; Lu, H.; Wang, X.; Jin, H. MicroRNAs as potential biomarkers in cancer: Opportunities and challenges. BioMed Res. Int. 2015, 2015, 125094. [CrossRef] [PubMed]

209. Mehta, S.; Shelling, A.; Muthukaruppan, A.; Lasham, A.; Blenkiron, C.; Laking, G.; Print, C. Predictive and prognostic molecular markers for cancer medicine. Ther. Adv. Med. Oncol. 2010, 2, 125-148. [CrossRef] [PubMed]

210. Zhang, H.; Li, T.; Zheng, L.; Huang, X. Biomarker MicroRNAs for diagnosis of oral squamous cell carcinoma identified based on gene expression data and MicroRNA-mRNA network analysis. Comput. Math. Methods Med. 2017, 2017, 9803018. [CrossRef]

211. Rapado-González, Ó.; López-López, R.; López-Cedrún, J.L.; Triana-Martínez, G.; Muinelo-Romay, L.; Suárez-Cunqueiro, M.M. Cell-Free microRNAs as potential oral cancer biomarkers: From diagnosis to therapy. Cells 2019, 8, 1653. [CrossRef]

212. Mazumder, S.; Datta, S.; Ray, J.G.; Chaudhuri, K.; Chatterjee, R. Liquid biopsy: miRNA as a potential biomarker in oral cancer. Cancer Epidemiol. 2019, 58, 137-145. [CrossRef] [PubMed]

213. Wong, T.S.; Liu, X.B.; Wong, B.Y.; Ng, R.W.; Yuen, A.P.; Wei, W.I. Mature miR-184 as potential oncogenic microRNA of squamous cell carcinoma of tongue. Clin. Cancer Res. Off. J. Am. Assoc. Cancer Res. 2008, 14, 2588-2592. [CrossRef] [PubMed]

214. Santhi, W.S.; Prathibha, R.; Charles, S.; Anurup, K.G.; Reshmi, G.; Ramachandran, S.; Jissa, V.T.; Sebastian, P.; Radhakrishna Pillai, M. Oncogenic microRNAs as biomarkers of oral tumorigenesis and minimal residual disease. Oral Oncol. 2013, 49, 567-575. [CrossRef] [PubMed]

215. Manikandan, M.; Deva Magendhra Rao, A.K.; Rajkumar, K.S.; Rajaraman, R.; Munirajan, A.K. Altered levels of miR-21, miR125b-2*, miR-138, miR-155, miR-184, and miR-205 in oral squamous cell carcinoma and association with clinicopathological characteristics. J. Oral Pathol. Med. Off. Publ. Int. Assoc. Oral Pathol. Am. Acad. Oral Pathol. 2015, 44, 792-800. [CrossRef] [PubMed]

216. Hui, A.B.; Lenarduzzi, M.; Krushel, T.; Waldron, L.; Pintilie, M.; Shi, W.; Perez-Ordonez, B.; Jurisica, I.; O'Sullivan, B.; Waldron, J.; et al. Comprehensive MicroRNA profiling for head and neck squamous cell carcinomas. Clin. Cancer Res. Off. J. Am. Assoc. Cancer Res. 2010, 16, 1129-1139. [CrossRef]

217. Childs, G.; Fazzari, M.; Kung, G.; Kawachi, N.; Brandwein-Gensler, M.; McLemore, M.; Chen, Q.; Burk, R.D.; Smith, R.V.; Prystowsky, M.B.; et al. Low-level expression of microRNAs let-7d and miR-205 are prognostic markers of head and neck squamous cell carcinoma. Am. J. Pathol. 2009, 174, 736-745. [CrossRef]

218. Kalfert, D.; Pesta, M.; Kulda, V.; Topolcan, O.; Ryska, A.; Celakovsky, P.; Laco, J.; Ludvikova, M. MicroRNA profile in site-specific head and neck squamous cell cancer. AntiCancer Res. 2015, 35, 2455-2463.

219. Severino, P.; Brüggemann, H.; Andreghetto, F.M.; Camps, C.; Klingbeil Mde, F.; de Pereira, W.O.; Soares, R.M.; Moyses, R.; Wünsch-Filho, V.; Mathor, M.B.; et al. MicroRNA expression profile in head and neck cancer: HOX-cluster embedded microRNA-196a and microRNA-10b dysregulation implicated in cell proliferation. BMC Cancer 2013, 13, 533. [CrossRef]

220. Lamperska, K.M.; Kozlowski, P.; Kolenda, T.; Teresiak, A.; Blizniak, R.; Przybyla, W.; Masternak, M.M.; Golusinski, P.; Golusinski, W. Unpredictable changes of selected miRNA in expression profile of HNSCC. Cancer Biomark. Sect. A Dis. Markers 2016, 16, 55-64. [CrossRef]

221. Maclellan, S.A.; Lawson, J.; Baik, J.; Guillaud, M.; Poh, C.F.; Garnis, C. Differential expression of miRNAs in the serum of patients with high-risk oral lesions. Cancer Med. 2012, 1, 268-274. [CrossRef] 
222. Sun, L.; Liu, L.; Fu, H.; Wang, Q.; Shi, Y. Association of decreased expression of serum mir-9 with poor prognosis of oral squamous cell carcinoma patients. Med Sci. Monit. Int. Med J. Exp. Clin. Res. 2016, 22, 289-294. [CrossRef]

223. Božinović, K.; Sabol, I.; Dediol, E.; Milutin Gašperov, N.; Manojlović, S.; Vojtechova, Z.; Tachezy, R.; Grce, M. Genome-wide miRNA profiling reinforces the importance of miR-9 in human papillomavirus associated oral and oropharyngeal head and neck cancer. Sci. Rep. 2019, 9, 2306. [CrossRef]

224. Reis, P.P.; Tomenson, M.; Cervigne, N.K.; Machado, J.; Jurisica, I.; Pintilie, M.; Sukhai, M.A.; Perez-Ordonez, B.; Grénman, R.; Gilbert, R.W.; et al. Programmed cell death 4 loss increases tumor cell invasion and is regulated by miR-21 in oral squamous cell carcinoma. Mol. Cancer 2010, 9, 238. [CrossRef]

225. Ganci, F.; Sacconi, A.; Manciocco, V.; Sperduti, I.; Battaglia, P.; Covello, R.; Muti, P.; Strano, S.; Spriano, G.; Fontemaggi, G.; et al. MicroRNA expression as predictor of local recurrence risk in oral squamous cell carcinoma. Head Neck 2016, 38 (Suppl. S1), E189-E197. [CrossRef]

226. Karimi, A.; Bahrami, N.; Sayedyahossein, A.; Derakhshan, S. Evaluation of circulating serum 3 types of microRNA as biomarkers of oral squamous cell carcinoma; A pilot study. J. Oral Pathol. Med. Off. Publ. Int. Assoc. Oral Pathol. Am. Acad. Oral Pathol. 2020, 49, 43-48. [CrossRef]

227. He, L.; Ping, F.; Fan, Z.; Zhang, C.; Deng, M.; Cheng, B.; Xia, J. Salivary exosomal miR-24-3p serves as a potential detective biomarker for oral squamous cell carcinoma screening. Biomed. Pharmacother. Biomed. Pharmacother. 2020, 121, 109553. [CrossRef]

228. Yan, Y.; Wang, X.; Venø, M.T.; Bakholdt, V.; Sørensen, J.A.; Krogdahl, A.; Sun, Z.; Gao, S.; Kjems, J. Circulating miRNAs as biomarkers for oral squamous cell carcinoma recurrence in operated patients. Oncotarget 2017, 8, 8206-8214. [CrossRef] [PubMed]

229. Momen-Heravi, F.; Trachtenberg, A.J.; Kuo, W.P.; Cheng, Y.S. Genomewide study of salivary MicroRNAs for detection of oral cancer. J. Dent. Res. 2014, 93 (Suppl. S7), 86S-93S. [CrossRef] [PubMed]

230. Pedersen, N.J.; Jensen, D.H.; Lelkaitis, G.; Kiss, K.; Charabi, B.W.; Ullum, H.; Specht, L.; Schmidt, A.Y.; Nielsen, F.C.; von Buchwald, C. MicroRNA-based classifiers for diagnosis of oral cavity squamous cell carcinoma in tissue and plasma. Oral Oncol. 2018, 83, 46-52. [CrossRef]

231. Liu, C.J.; Lin, S.C.; Yang, C.C.; Cheng, H.W.; Chang, K.W. Exploiting salivary miR-31 as a clinical biomarker of oral squamous cell carcinoma. Head Neck 2012, 34, 219-224. [CrossRef]

232. Lu, Z.; He, Q.; Liang, J.; Li, W.; Su, Q.; Chen, Z.; Wan, Q.; Zhou, X.; Cao, L.; Sun, J.; et al. miR-31-5p is a potential circulating biomarker and therapeutic target for oral cancer. Mol. Ther. Nucleic Acids 2019, 16, 471-480. [CrossRef] [PubMed]

233. Ayaz, L.; Görür, A.; Yaroğlu, H.Y.; Ozcan, C.; Tamer, L. Differential expression of microRNAs in plasma of patients with laryngeal squamous cell carcinoma: Potential early-detection markers for laryngeal squamous cell carcinoma. J. Cancer Res. Clin. Oncol. 2013, 139, 1499-1506. [CrossRef] [PubMed]

234. Hung, P.S.; Liu, C.J.; Chou, C.S.; Kao, S.Y.; Yang, C.C.; Chang, K.W.; Chiu, T.H.; Lin, S.C. miR-146a enhances the oncogenicity of oral carcinoma by concomitant targeting of the IRAK1, TRAF6 and NUMB genes. PLoS ONE 2013, 8, e79926. [CrossRef]

235. Emami, N.; Mohamadnia, A.; Mirzaei, M.; Bayat, M.; Mohammadi, F.; Bahrami, N. miR-155, miR-191, and miR-494 as diagnostic biomarkers for oral squamous cell carcinoma and the effects of Avastin on these biomarkers. J. Korean Assoc. Oral Maxillofac. Surg. 2020, 46, 341-347. [CrossRef] [PubMed]

236. Yang, C.C.; Hung, P.S.; Wang, P.W.; Liu, C.J.; Chu, T.H.; Cheng, H.W.; Lin, S.C. miR-181 as a putative biomarker for lymph-node metastasis of oral squamous cell carcinoma. J. Oral Pathol. Med. Off. Publ. Int. Assoc. Oral Pathol. Am. Acad. Oral Pathol. 2011, 40, 397-404. [CrossRef]

237. Wittmann, J.; Jäck, H.M. Serum microRNAs as powerful cancer biomarkers. Biochim. Biophys. Acta 2010, 1806, 200-207. [CrossRef]

238. Liu, C.J.; Lin, J.S.; Cheng, H.W.; Hsu, Y.H.; Cheng, C.Y.; Lin, S.C. Plasma miR-187* is a potential biomarker for oral carcinoma. Clin. Oral Investig. 2017, 21, 1131-1138. [CrossRef]

239. Lu, Y.C.; Chang, J.T.; Huang, Y.C.; Huang, C.C.; Chen, W.H.; Lee, L.Y.; Huang, B.S.; Chen, Y.J.; Li, H.F.; Cheng, A.J. Combined determination of circulating miR-196a and miR-196b levels produces high sensitivity and specificity for early detection of oral cancer. Clin. Biochem. 2015, 48, 115-121. [CrossRef] [PubMed]

240. Liu, C.J.; Tsai, M.M.; Tu, H.F.; Lui, M.T.; Cheng, H.W.; Lin, S.C. miR-196a overexpression and miR-196a2 gene polymorphism are prognostic predictors of oral carcinomas. Ann. Surg. Oncol. 2013, 20 (Suppl. S3), S406-S414. [CrossRef] [PubMed]

241. Sun, G.; Cao, Y.; Wang, P.; Song, H.; Bie, T.; Li, M.; Huai, D. miR-200b-3p in plasma is a potential diagnostic biomarker in oral squamous cell carcinoma. Biomark. Biochem. Indic. Expo. Response Susceptibility Chem. 2018, 23, 137-141. [CrossRef]

242. Chang, K.W.; Liu, C.J.; Chu, T.H.; Cheng, H.W.; Hung, P.S.; Hu, W.Y.; Lin, S.C. Association between high miR-211 microRNA expression and the poor prognosis of oral carcinoma. J. Dent. Res. 2008, 87, 1063-1068. [CrossRef] [PubMed]

243. Gai, C.; Camussi, F.; Broccoletti, R.; Gambino, A.; Cabras, M.; Molinaro, L.; Carossa, S.; Camussi, G.; Arduino, P.G. Salivary extracellular vesicle-associated miRNAs as potential biomarkers in oral squamous cell carcinoma. BMC Cancer 2018, 18, 439. [CrossRef]

244. Lin, S.C.; Liu, C.J.; Lin, J.A.; Chiang, W.F.; Hung, P.S.; Chang, K.W. miR-24 up-regulation in oral carcinoma: Positive association from clinical and in vitro analysis. Oral Oncol. 2010, 46, 204-208. [CrossRef] [PubMed]

245. Zhao, J.; Hu, C.; Chi, J.; Li, J.; Peng, C.; Yun, X.; Li, D.; Yu, Y.; Li, Y.; Gao, M.; et al. miR-24 promotes the proliferation, migration and invasion in human tongue squamous cell carcinoma by targeting FBXW7. Oncol. Rep. 2016, 36, 1143-1149. [CrossRef] 
246. Park, N.J.; Zhou, H.; Elashoff, D.; Henson, B.S.; Kastratovic, D.A.; Abemayor, E.; Wong, D.T. Salivary microRNA: Discovery, characterization, and clinical utility for oral cancer detection. Clin. Cancer Res. Off. J. Am. Assoc. Cancer Res. 2009, 15, 5473-5477. [CrossRef] [PubMed]

247. Yang, Y.; Li, Y.X.; Yang, X.; Jiang, L.; Zhou, Z.J.; Zhu, Y.Q. Progress risk assessment of oral premalignant lesions with saliva miRNA analysis. BMC Cancer 2013, 13, 129. [CrossRef]

248. To, K.K.W.; Fong, W.; Tong, C.W.S.; Wu, M.; Yan, W.; Cho, W.C.S. Advances in the discovery of microRNA-based anticancer therapeutics: Latest tools and developments. Expert Opin. Drug Discov. 2020, 15, 63-83. [CrossRef]

249. Bai, Z.; Wei, J.; Yu, C.; Han, X.; Qin, X.; Zhang, C.; Liao, W.; Li, L.; Huang, W. Non-viral nanocarriers for intracellular delivery of microRNA therapeutics. J. Mater. Chem. B 2019, 7, 1209-1225. [CrossRef] [PubMed]

250. Shah, M.Y.; Ferrajoli, A.; Sood, A.K.; Lopez-Berestein, G.; Calin, G.A. microRNA therapeutics in cancer-An emerging concept. EBioMedicine 2016, 12, 34-42. [CrossRef]

251. Baumann, V.; Winkler, J. miRNA-based therapies: Strategies and delivery platforms for oligonucleotide and non-oligonucleotide agents. Future Med. Chem. 2014, 6, 1967-1984. [CrossRef]

252. Chen, Y.; Gao, D.Y.; Huang, L. In vivo delivery of miRNAs for cancer therapy: Challenges and strategies. Adv. Drug Deliv. Rev. 2015, 81, 128-141. [CrossRef] [PubMed]

253. Rupaimoole, R.; Slack, F.J. MicroRNA therapeutics: Towards a new era for the management of cancer and other diseases. Nat. Rev. Drug Discov. 2017, 16, 203-222. [CrossRef]

254. Beavers, K.R.; Nelson, C.E.; Duvall, C.L. MiRNA inhibition in tissue engineering and regenerative medicine. Adv. Drug Deliv. Rev. 2015, 88, 123-137. [CrossRef] [PubMed]

255. Fu, Y.; Chen, J.; Huang, Z. Recent progress in microRNA-based delivery systems for the treatment of human disease. ExRNA 2019, 1, 24. [CrossRef]

256. Hashiguchi, Y.; Kawano, S.; Goto, Y.; Yasuda, K.; Kaneko, N.; Sakamoto, T.; Matsubara, R.; Jinno, T.; Maruse, Y.; Tanaka, H.; et al. Tumor-suppressive roles of $\Delta \mathrm{Np} 63 \beta$-miR-205 axis in epithelial-mesenchymal transition of oral squamous cell carcinoma via targeting ZEB1 and ZEB2. J. Cell. Physiol. 2018, 233, 6565-6577. [CrossRef]

257. Weng, J.; Zhang, H.; Wang, C.; Liang, J.; Chen, G.; Li, W.; Tang, H.; Hou, J. miR-373-3p targets DKK1 to promote EMT-induced metastasis via the Wnt/ $\beta$-Catenin pathway in tongue squamous cell carcinoma. BioMed Res. Int. 2017, 2017, 6010926. [CrossRef]

258. Jiang, F.; Zhao, W.; Zhou, L.; Liu, Z.; Li, W.; Yu, D. MiR-222 targeted PUMA to improve sensitization of UM1 cells to cisplatin. Int. J. Mol. Sci. 2014, 15, 22128-22141. [CrossRef] [PubMed]

259. Morgan, D.; Garg, M.; Tergaonkar, V.; Tan, S.Y.; Sethi, G. Pharmacological significance of the non-canonical NF-kB pathway in tumorigenesis. Biochim. Biophys. Acta Rev. Cancer 2020, 1874, 188449. [CrossRef] [PubMed]

260. Li, F.; Shanmugam, M.K.; Siveen, K.S.; Wang, F.; Ong, T.H.; Loo, S.Y.; Swamy, M.M.; Mandal, S.; Kumar, A.P.; Goh, B.C.; et al. Garcinol sensitizes human head and neck carcinoma to cisplatin in a xenograft mouse model despite downregulation of proliferative biomarkers. Oncotarget 2015, 6, 5147-5163. [CrossRef]

261. Shanmugam, M.K.; Ong, T.H.; Kumar, A.P.; Lun, C.K.; Ho, P.C.; Wong, P.T.; Hui, K.M.; Sethi, G. Ursolic acid inhibits the initiation, progression of prostate cancer and prolongs the survival of TRAMP mice by modulating pro-inflammatory pathways. PLoS ONE 2012, 7, e32476. [CrossRef] [PubMed]

262. Li, F.; Shanmugam, M.K.; Chen, L.; Chatterjee, S.; Basha, J.; Kumar, A.P.; Kundu, T.K.; Sethi, G. Garcinol, a polyisoprenylated benzophenone modulates multiple proinflammatory signaling cascades leading to the suppression of growth and survival of head and neck carcinoma. Cancer Prev. Res. 2013, 6, 843-854. [CrossRef] [PubMed] 